\title{
A Systematic Review and Synthesis of Qualitative Research: The Influence of School Context on Symptoms of Attention Deficit Hyperactivity
}

\section{Disorder}

\author{
Ruth Gwernan-Jones ${ }^{\mathrm{a}, *}$, Darren A. Moore ${ }^{\mathrm{d}}$, Paul Cooper ${ }^{\mathrm{b}}$, Abigail Emma \\ Russell $^{\mathrm{a}}$, Michelle Richardson ${ }^{\mathrm{c}}$, Morwenna Rogers ${ }^{\mathrm{d}}$, Jo Thompson-Coon ${ }^{\mathrm{d}}$, Ken \\ Stein $^{\mathrm{d}}$, Tamsin J. Ford ${ }^{\mathrm{a}}$ and Ruth Garside ${ }^{\mathrm{a}}$ \\ a University of Exeter Medical School, University of Exeter, Exeter, UK
}

b Brunel University, London, UK

c University College London Institute of Education, London, UK

d NIHR CLAHRC South West Peninsula (PenCLAHRC), University of Exeter Medical

School, University of Exeter

* Corresponding author: R.C.Gwernan-Jones@Exeter.ac.uk. Dr Ruth Gwernan-Jones, South

Cloisters, St Luke's Campus, University of Exeter, Heavitree Road, Exeter, EX1 2LU, UK

\begin{abstract}
Acknowledgements
Preparation of this article was supported in part by a grant from the National Institute for Health Research Health Technology Assessment (NIHR HTA) programme (project number 10/140/02) and the NIHR

Collaboration for Leadership in Applied Health Research and Care South West Peninsula (PenCLAHRC). The European Centre for Environment and Human Health, with which Ruth Garside is affiliated, is supported by investment from the European Development Fund and the European Social Fund Convergence Programme for Cornwall and the Isles of Scilly. The views and opinions expressed in this article are those of the authors and do not necessarily reflect those of the HTA programme, NIHR, NHS, the Department of Health or the EU. We would also like to thank the parents who commented on the interim results of this review, Brahm Norwich for giving comments on an early draft of the review, and Rebecca Abbot, Rebecca Whear and Tamsin NewloveDelgado for their work on screening titles/abstracts.
\end{abstract}

Word count: 7,765 


\title{
A Systematic Review and Synthesis of Qualitative Research: The Influence of School Context on Symptoms of Attention Deficit Hyperactivity Disorder
}

\begin{abstract}
(word count: 150)
This systematic review and synthesis of qualitative research explored contextual factors relevant to non-pharmacological interventions for Attention Deficit Hyperactivity Disorder (ADHD) in schools. We conducted meta-ethnography to synthesise 34 studies, using theories of stigma to further develop the synthesis. Studies suggested that the classroom context requiring pupils to sit still, be quiet and concentrate could trigger symptoms of ADHD, and that symptoms could then be exacerbated through informal/formal labelling and stigma, damaged self-perceptions and resulting poor relationships with staff and pupils. Influences of the school context on symptoms of ADHD were often invisible to teachers and pupils, with most attributions made to the individual pupil and/or the pupil's family. We theorise that this 'invisibility' is at least partly an artefact of stigma, and that the potential for stigma for ADHD to seem 'natural and right' in the context of schools needs to be taken into account when planning any intervention.
\end{abstract}

Keywords: Attention Deficit Hyperactivity Disorder; ADHD; school stigma; attributions; qualitative research; meta-ethnography

\section{Introduction}

Clinical guidelines emphasise integrated care that involves both pharmacological and nonpharmacological treatment for Attention Deficit Hyperactivity Disorder (ADHD) (NICE 2013, Wolraich et al. 2011). Whereas the effectiveness of medication is well established in reducing symptoms of ADHD (Coghill 2004), such reduction of symptoms does not necessarily align with increased engagement and educational performance in pupils (Purdie, Hattie, and Carroll 2002). In addition, children respond variably to pharmacological treatment, with some experiencing negative side effects, little improvement in symptoms or 
resistance to medication. For such children non-pharmacological treatment is particularly relevant. The effectiveness of non-pharmacological treatment and factors that limit and/or enhance such interventions in schools is therefore an important research topic. Systematic reviews have reported beneficial effects of non-pharmacological interventions conducted in schools and other settings (DuPaul, Eckert, and Vilardo 2012, Evans et al. 2014, Pelham and Fabiano 2008, Sonuga-Barke et al. 2013). To our knowledge however, there have been no systematic reviews focused on exploring contextual factors that may be relevant to the delivery of non-pharmacological interventions for ADHD in schools.

Systematic reviews involve the use of transparent methods to locate, consider, quality appraise and synthesise research with the aim of preventing bias. Initially developed in a healthcare context to synthesise quantitative trial data, systematic reviews are increasingly used in other disciplines such as business studies and education (Petticrew and Roberts 2006). Systematic reviews of qualitative research are gaining credibility for their capacity to explore questions about processes of interventions, the socio-cultural contexts in which interventions take place and how these may interact with intervention effectiveness, as well as the perceptions people have about conditions, treatment and service (Pearson 2004).

The studies reported in this paper address the research question; "What are the schoolrelated experiences and perceptions of pupils diagnosed with or at risk of ADHD, their teachers, parents and peers?". This review was conducted in the context of a wider series of systematic reviews, the overarching aim of which was to evaluate non-pharmacological interventions delivered in school settings for pupils with, or at risk of, ADHD and to explore the factors that may enhance, or limit, their beneficial delivery (Richardson et al., 2015). In response to the findings of included studies about the school context, and consideration of theories of stigma (Goffman 1990, Thornicroft 2006), we further focused our synthesis to institutional (school) level stigma. 


\section{The contested nature of ADHD}

The current Diagnostic and Statistical Manual of Mental Disorders (DSM-5) describes ADHD as a neurodevelopmental disorder characterised by age-inappropriate levels of inattention, impulsivity and hyperactivity (APA 2013). The aetiology of ADHD is complex and may be most clearly understood as involving the interplay of biological, psychological and social factors (Barkley 1990). The syndrome involves uncertainties, such as its relatively new status as a childhood disorder, the ethics of prescribing drugs to children over the long term, particularly to "control" behaviour, and the lack of a biomedical indicator to substantiate diagnosis. Such ambiguities have stimulated considerable debate and sometimes conflicting views over the disorder's validity within and between researchers, the media, practitioners and parents (Pajo and Cohen 2012). For example, in O'Regan's UK study (2009), 50\% of General Practitioners and 20\% of Special Educational Needs Coordinators did not believe that ADHD was a "real" condition (p. 4). Such difference in opinion about the nature of ADHD may contribute to uncertainties within schools about how to intervene with pupils diagnosed with or at risk of ADHD.

\section{Method}

The methods used to identify and select evidence followed the methodological approach recommended by the University of York's Centre for Reviews and Dissemination (CRD 2009). A registered protocol for this review and other associated systematic reviews was developed with input from topic experts, parents and educators (PROSPERO CRD4201100****). 


\section{Identification of evidence}

\section{Inclusion criteria}

The following inclusion and exclusion criteria were used to determine eligibility.

Population. Those with experience of ADHD in school settings, including pupils diagnosed with or at risk of ADHD, aged four to 18 years, their parents, teachers and peers.

Methods. Primary research using qualitative data collection and analysis.

Outcomes. Experiences and perceptions related to ADHD in schools.

Location and language. Only papers from countries belonging to the Organisation for Economic Co-operation and Development (OECD) and written in English were included to prevent distortion following from language translation or substantial cultural difference.

Date. Only studies conducted from 1980 onwards were included, reflecting significant changes to the diagnosis of ADHD that year (APA 1980).

\section{Search strategy}

A database search strategy was developed in consultation with education and child mental health practitioners. It consisted of; 1) terms related to ADHD, 2) terms related to school contexts, 3) a bespoke qualitative research filter. It used a mixture of subject headings (controlled vocabulary) and free text terms. Twenty electronic databases were searched during July 2012 and again in March 2013: MEDLINE, EMBASE, PsycINFO, Health Management Information Consortium (via OvidSP); ASSIA, British Education Index, Australian Education Index, ERIC (via ProQuest); Education Research Complete (via EBSCOhost); The Cochrane Library (CDSR, DARE, CENTRAL, CMR, HTA, NHS EED); The Campbell Library; Social Sciences Citation Index; Conference Proceedings Citation 
Index; Conference Proceedings Citation Index - Social Science and Humanities (via ISI Web of Science). For an example search strategy used for the MEDLINE/OvidSp database, please contact the corresponding author.

Forward and backward citation chasing, consultation with expert advisors and hand searching of key journals were completed to identify additional relevant work. EndNote X7 reference management software was used to organise the search results, screening and full text retrieval processes.

\section{Study selection}

Two reviewers conducted title/abstract screening independently for each record (six researchers shared this screening: RGJ, DM, TND, RW, RA, MRo). Full texts of potentially relevant records were obtained where possible, and were screened independently by two reviewers (RGJ, DM) for inclusion and exclusion. Disagreements were resolved through discussion (RGJ, DM).

\section{Data extraction}

Data was extracted using a form adapted from a previous Cochrane systematic review (Husk et al. 2013) and was piloted by two reviewers (RGJ, DM). Data on the study design, participants and findings were extracted into NVivo v.9.2 by RGJ and checked by DM. Where papers acknowledged qualitative analysis but did not provide sufficient detail, and contact details were available, authors were emailed to request further information.

\section{Quality assessment}

Study quality was assessed using a checklist adapted from Wallace et al. (2004) consisting of 15 sensitising 'prompts' (see online Supplementary Table 1). Positive, negative and neutral appraisal scores were collated for each item and each paper. Quality appraisal decisions were 
made independently by two reviewers (RGJ, DM), and disagreements were resolved through discussion.

\section{Methods of analysis/synthesis}

Data analysis and synthesis broadly followed the principles of meta-ethnography (Noblit and Hare 1988) in a process of 'translation' between studies, where the themes from each study were compared. Refutation involved the explanation of contradictory findings. A 'line-ofargument' or overarching theme was created by synthesising translational and refutational findings across studies into a coherent whole. Although described linearly, the process was cyclical and iterative.

We found the application of meta-ethnography across some qualitative studies to be difficult when authors described data using categories without developing themes, offering little in the way of concepts to translate. We responded to this in two ways identified from other qualitative syntheses; 1) the selection of an index paper to act as an organizing thematic reference against which other studies could be compared (Campbell et al. 2011) and 2) thematic development of descriptive categories (Smithson, Garside, and Pearson 2011). Thematic analysis and translation between study themes were supported by software, where NVivo coding and refinement capacities were applied to extracted data and the developed codes were used to create and refine concept maps in Microsoft Word. Papers were grouped by participant type (Pupils, Teachers, Parents, Mixed) before combining these into the final overarching theme in a staged process of synthesis (Popay et al. 2006).

\section{Findings}

\section{Study characteristics}

A total of 34 studies reported in 37 papers were included (Figure 1). Number of studies by 
participant type is given in Table 1. Two studies were reported in multiple publications (Exley 2006, 2007, 2008; Malacrida 2001, 2004); when discussing information from these studies, only one journal article each (Exley 2008; Malacrida 2001) will be cited in order to signify the studies' singular nature.

The majority of studies were located in the US (16 of 34). Pupils attended a range of private, mainstream and special preschools, elementary (or primary) and middle/high (or secondary) schools. Across studies, 258 pupils, 389 teachers and 302 parents participated (see online Supplementary Table 2). Young people (aged 12 to 18) represent the majority of pupil participants. By contrast, most teacher participants taught children diagnosed with or at risk of ADHD in preschool and primary years (ages 4-11).

\section{Study Methods}

Authors in 26 of the 34 studies collected data through semi-structured interviews alone (15 studies) or used semi-structured interviews alongside other methods such as observation (4), questionnaires (4), focus groups (3), a range of child-friendly activities (2) and group narratives (1). Eight studies did not involve semi-structured interviews, but collected data through observation (2), focus groups (2), vignettes (2), internet forum messages (1) or narratives (1).

Many authors described their chosen research methodologies:

- Discourse Analysis (1),

- Ethnography (3),

- Grounded Theory (6),

- Narrative approaches (2) and

- Phenomenology (5). 
Other authors did not describe methodologies, but did use theoretical frameworks for data collection and/or analysis (13). A minority of authors were not explicit about their chosen research methodologies or underpinning theory (4). For further details of included study characteristics see online Supplementary Table 3.

\section{Quality appraisal}

All but five studies met at least 10/14 appraisal criterion, suggesting a large majority were of good quality (see online Supplementary Table 4). The areas in which studies were most often lacking involved the omission of a discussion about study limitations (17) or aspects of generalisability (16), or study authors were not reflexive (18).

\section{The overarching theme}

The contribution of included studies to each review theme is shown in Table 3. It is commonly accepted within interpretive research that themes are developed through interpretations by researchers and that they may be developed in more than one way (Saldana 2009). We judged the importance of potential themes in relation to our overall research question regarding implementation of interventions for ADHD within schools. To identify the overarching theme 'The influence of school context on symptoms of ADHD' we drew from a theoretical framework used by a number of the included studies, that of stigma. We will first briefly discuss the theories of stigma we applied in our synthesis in order to provide a foundation from which to give the review findings.

\section{Stigma}

Stigma is a concept developed within the field of social psychology, particularly well expressed by Goffman (Goffman 1990). Goffman describes stigma as the disgrace incurred upon those categorised with attributes outside what is considered to be ordinary and natural; 
'an undesired differentness' that leads us to 'believe the person with a stigma is not quite human' justifying us to 'exercise varieties of discrimination, through which we effectively, if often unthinkingly, reduce his [sic] life chances' (p15). Such disgrace can result in the 'spoiled identity' of the person who is stigmatised, as they internalise as accurate others' judgment of themselves as undesirable. Thornicroft (2006) further discusses stigma in relation to mental illness by distinguishing aspects of ignorance, prejudice and discrimination. Importantly, the attributes that provoke stigma are not discrediting in and of themselves, but only according to the value systems of the context from which they are allocated. Thornicroft emphasises the protective functions of stigma in perpetuating established institutional structures, rather than it originating in intentions to inflict personal harm (although this may indeed be its result):

- 'Stigma originates in a universal human tendency to avoid danger. Stigmatisation is not therefore mainly directed against individuals, but against those who are understood to pose a threat. Such understandings are socially created, and individual 'stigmatisers' are essentially only repeating (and recreating) their society's norms about what are appropriate feelings and behaviours to display to members of any threatening group.' (Thornicroft 2006, p.189)

- Stigmatization is carried out in a process of labelling that involves the assignment of a category name that invokes the stigma onto a person, and can be informal or formal. An example of informal labelling of ADHD symptoms is 'naughty boy'; formal labelling of ADHD symptoms would involve clinical diagnosis of ADHD.

Mechanisms of discrimination described by Goffman (1990) include:

- Generalising the particular faulty attribute to a wider gestalt of disability (for example assuming a child with ADHD is unintelligent or not capable of learning); 
- Assuming the pupil exhibits the range of attributes by which the label is understood rather than seeking to understand the pupil and/or the pupil's specific circumstances (for example a person who believes ADHD results from poor parenting may assume a child's disruptive behaviour is due to a lack of discipline at home);

- The pupil's and/or families' behaviour may be understood as an expression of the stigmatised attribute whereas the same behaviour from non-stigmatised peers and/or their families would not be regarded in the same way (for example a reward given by a parent to a child for good behaviour might be considered by a teacher to be an example of the parent 'spoiling' the child).

Many included studies explicitly mentioned stigma in relation to ADHD (Bailey and Thomson 2009, Carpenter and Austin 2008, Cooper and Shea 1998, Exley 2008, Kendall et al. 2003, Koro-Ljungberg et al. 2011, Malacrida 2001, McMahon 2012, Prosser 2006, Rafalovich 2005, Shea and Wiener 2003, Singh 2011, Watson 2011). Other studies described institutional mechanisms and/or negative personal experiences that were in line with the concepts of stigma without defining them as such (Friio 1999, Hibbitts 2010, Houghton et al. 2006, Kendall et al. 2003, Shea and Wiener 2003). It is the aim of this article to focus on institutional processes of stigma rather than detailing personal experiences of being stigmatised, as argued by Thornicroft (2006). However we also emphasise the need to regard each issue in combination with other factors. We seek to redress a balance in understanding and response to complex issues surrounding ADHD that have been dominated by conceptions of within-pupil differences and/or contributions of home life, while neglecting the influence of schools.

We identified the overarching theme, 'The influence of school context on symptoms of ADHD', with three subthemes: 
- School context and the aggravation of ADHD symptoms;

- Delineating deviance and invoking stigma; and

- The relationship between stigma and attributions for ADHD.

These will be discussed in turn below.

School context and the aggravation of ADHD symptoms

A number of study authors and parent and/or pupil participants commented that school was the context where ADHD difficulties were most apparent (Brice 1998; Carpenter and Austin 2008; Friio 1999; Malacrida 2001; McDannel 2005; Prosser 2006; Watson 2011). Findings from included studies suggest the school context contributes to the aggravation of ADHD symptoms because of classroom expectations and conflict in relationships.

Some studies conducted with pupils diagnosed with ADHD described the classroom context to be a trigger to ADHD symptoms, and pupils described the classroom as leaving them feeling frustrated, angry, drained and/or imprisoned (Brice 1998; Cooper and Shea 1998; Friio 1999; Hands 2010; Houghton et al. 2006; Kendall et al. 2003; Prosser 2006; Shea and Wiener 2003). Pupils found the need to concentrate and remain still for long periods of time highly challenging, and preferred more active learning that was meaningful to them (Brice 1998; Kendall et al. 2003). Many of these pupils experienced peer interactions, noise and movement in classrooms as distractions whereas some described success in learning outside the context of school (Brice 1998; Cooper and Shea 1998; Friio 1999; Houghton et al. 2006; Kendall et al. 2003; McDannel 2005).

McDannel (2005), in response to classroom observations, concluded that ADHD symptoms like hyperactivity and inattention were often an unconscious self-regulatory response that pupils resorted to in order to cope with demands of the classroom. Similar experiences were described by pupils in other studies, 
I'll like start going like this (rubbing his hands) and twiddling my thumbs. I move my feet a lot and look at other stuff and move my head a lot ... if I stop... I feel really funny so I keep on going. If I stop, well like I just start again. I don't know why ... I feel more comfortable when I start fidgeting again. (Friio 1999, p111, Canadian young person aged $14-18$, reviewer edits)

Rather than "bad behaviour", McDannel (2005) suggested symptoms of ADHD could be understood to be clues about pupil needs. The same study identified that the pupil participants were more able to learn in quiet, ordered classrooms than in dynamic, less structured classrooms.

Pupils also described an escalation of negative emotions and difficulties in relationships over the course of their school careers, where these could compound alreadypresent ADHD-related difficulties with emotional self-regulation and control (Hands 2010; Houghton et al. 2006; Kendall et al. 2003; Shea and Wiener 2003). Studies described different aspects of this issue, for example as escalating 'stress' (Houghton et al. 2006) or anger escalating to a sense of rage (Hands 2010; Hibbitts 2010; Shea and Wiener 2003). Some studies link this behaviour to pupil perception of injustice from teachers and peers, for example in response to over-punitive teachers who punish them for behaviour for which peers are not punished, and some pupils admitted to behaving badly on purpose with teachers whom they believed had treated them unfairly (Friio 1999; Hands 2010; Hibbitts 2010; Houghton et al. 2006; Hughes 2007; Prosser 2006; Singh 2011). Participants also described escalating stress and loss of emotional control in response to bullying, where pupils diagnosed with ADHD were baited in order to see if they would lose their temper (Exley 2008; Houghton et al. 2006; Rafalovich 2005; Shea and Wiener 2003; Singh 2011). Such findings suggest that some expression of ADHD-related behaviour may be a pupil response to the marginalization and/or social exclusion they face in response to stigma.

Delineating deviance and invoking stigma 
Four papers explored school-level stigmatisation (Bailey and Thomson 2009; Carpenter and Austin 2008; Rafalovich 2005; Watson 2011). This centred around the power of school staff to decide what acceptable and unacceptable behaviour was, and their response to behaviour considered unacceptable. These findings demonstrate the arbitrary, local nature of the boundary between 'acceptable' and 'unacceptable' behaviour, and the contribution of school staff to this process. Although different sociological theories were used to analyse these studies, the findings parallel each other in illuminating the interactional nature of pupil behaviour and school structures and ethos, and the inadequacy of conceptualising ADHD symptoms through the lens of the individual pupil only. All four study authors referred to their findings as processes of stigmatisation.

Three papers discussed the role of schools in establishing boundaries for 'good' and 'bad' behaviour. Bailey and Thomson's (2009) study focused on the contribution of school classroom routines to the evaluation of behaviour. Through participant observation Bailey identified classroom routines that established 'correct' behaviour, for example rules for entering and exiting the classroom. Deeply-held understanding of the "good teacher" role in the prevention of disruption within the classroom meant that teachers worked hard to enforce such routines through punishment and communication with Headteachers, Special Educational Needs Coordinators, or parents. Through these teacher-determined routines, children were taught how to behave in school, and through the performance of these routines teachers established whether children fell inside or outside norms for acceptable behaviour.

On his arrival as a teaching assistant (TA), Bailey was given a list of six children who were 'ones to watch'. These children were often topics of conversation, where teachers and TAs kept each other abreast of breaches in the children's behaviour. The children were not the only topic of interest; the children's parents were also discussed, 
[The classroom teacher] described [Christopher's mother] as 'carrying a lot of emotional baggage', saying that she had 'broken down' during [a] meeting. [The classroom teacher] clearly didn't think much of her as a parent and thought Christopher was probably spoilt. (Bailey and Thomson 2009, p216, pupil aged 5-6, reviewer edits)

The authors note that discussion about poor behaviour by a child was frequently linked to discussion of family circumstances; this repeats the frequent link teachers made in other studies between ADHD symptoms and 'poor parenting' (see the subtheme on attributions). The authors also comment that the magnitude of the scrutiny these children were under was likely to increase the amount of problematic behaviour identified regardless of the quality of their behaviour in comparison to peers who were not watched so closely. This provides an example of the process of stigmatization.

Bailey and Thomson (2009) do not argue that school classroom routines are solely negative, instead they acknowledge their productive, essential nature. However, the authors do expose the 'dangerous and damaging' effect such routines may have for a minority of children who do not or cannot meet expectations. This study suggests that the behaviour of teachers follows socially constructed norms where they are held accountable for keeping order and producing particular levels of achievement. Processes of stigma, where pupils are singled out through surveillance, segregation and other structural means, are methods teachers draw on to adequately perform their role.

Carpenter and Austin (2008), drawing from feminist theory and theories of mother blame, similarly explore the way that schools constitute the notion of 'disorderly behaviour'. The child whose behaviour lies outside whatever local boundaries for accepted behaviour might be, and their mother, tend to be stigmatised and devalued in the process of addressing problem behaviours. The authors find that mothers advocate on the behalf of their children, either to reframe their child's behaviour as normal by school standards, or to seek diagnosis and medication for ADHD in order to change the child to fit school expectations. 
Watson's (2011) narrative analysis illustrated the arbitrary nature of school boundaries for acceptable and unacceptable behaviour;

... the appointments became routine to discuss and review his intolerable behaviour. Surprisingly we never discussed: violence, fighting, abuse, deceit, dishonesty or any other behaviour I consider unacceptable. We spoke about; not sitting still, walking around class, talking to other children, not finishing set work or homework and [coming to school without a tie]. (Watson 2011, p22, British mother of a son aged 9-11, reviewer edits)

This account drew from theories of satire to highlight the potentially farcical nature of ADHD, where she and her son were stigmatised for, and her son was punished by school staff and ultimately medicated for, ordinary behaviours.

Finally, Rafalovich (2005) explored the process by which interactions between parents, teachers and clinicians transform children's normalised troubles into formalised deviance. He identified a turning point in the transformation from informal to formal labelling to be the School Based Team (SBT) meeting, where current and previous teachers of the pupil, a school psychologist and/or the school principal might meet, in addition to parents, to discuss academic and behavioural difficulties of a pupil with inference about the cause of these difficulties. Rafalovich noted that such meetings often signalled a shift from the normalization of a child's difficulties (e.g. understanding them to be a phase) to understanding them as deviant (e.g. a symptom of a disorder). One mother described a SBT meeting;

I thought we would be able to have a conversation about what was going on, but there was none of that. The school had already made up their minds ... So, there I am trying to defend my daughter and they didn't even want to listen ... they never gave her any other options for her school lessons. They try to cookie-cutter the kids all the same. She has lots of things that she is very capable of, but they never took the time to try and help her with some of those. (Rafalovich 2005, p37, North American mother of a daughter aged 6-17, reviewer edits) 
The mother suspected that the school had come to conclusions about her daughter before the meeting, and she found her perceptions about her daughter, which included positive, normalising interpretations, to be dismissed. Similar experiences were described by parents in other studies (Hands 2010; Hibbitts 2010; Malacrida 2001; Reid et al. 1996; Watson 2011). Rather than understanding her child as having ADHD, she thought the school had not met her child's educational needs adequately. Nonetheless, the child was referred to a clinician and diagnosed with ADHD, and prescribed Ritalin. Rafalovich's (2005) study therefore demonstrates from another angle that ADHD is an interaction between the child and expectations of educational staff in a specific context.

These studies describe the way schools determined boundaries for acceptable behaviour, with differences at the local level. Processes that marked particular pupils as different from their peers held the potential for stigma, however stigma only resulted when the pupil was marginalised through acts of discrimination - there were also findings for constructive, inclusive responses from teachers to symptoms of ADHD, and these were noted to be powerful in their ability to reduce the expression of symptoms in school (Guevara et al. 2005; Hands 2010; Hibbitts 2010; Hong 2008; Lee 2008; Margalit et al. 2010; Reid et al. 1996; for further discussion see Gwernan-Jones et al. 2015). However, stigma was reported more frequently. The predominance of this finding suggests that the marginalization associated with stigma was common in schools in relation to pupils diagnosed with or at risk of ADHD. Beyond the personal damage to the pupil and the pupil's family, stigma could further aggravate ADHD-related behaviour in pupils, as was discussed in the section above.

The relationship between stigma and attributions for ADHD

Attributions are beliefs people hold about the causes for the behaviour of themselves and others (Heider 1958). Attributional beliefs can act as a logical foundation for the decisions 
people make about how to manage situations (Weiner 1985), and so are implicated in personal action. Attributions were found to be important by a number of study authors in relation to the management of ADHD in schools.

Attributions form the basis for one of the puzzling findings of this review: the mismatch between the experiences of ADHD pupils and teachers described, which linked individual behaviours to specific contexts and relationships, and the attributional beliefs that they expressed about ADHD. Participants tended to attribute symptoms to a single cause rather than explain them as a response to an interaction of factors.

Hughes (2007) summarised common differences in attributions for symptoms of ADHD between teachers, pupils and parents, and the potential impacts of this on intervention, which were supported by the findings in many other studies:

- They may disagree on the extent of control the child has, and whether the behaviour results from biological or sociological influences (Arcia et al. 2000; Cooper and Shea 1998; Einarsdottir 2008; Exley 2008; Hillman 2011; Houghton et al. 2006; Hughes 2007; Kendall et al. 2003; McMahon 2012; Prosser 2006; Rafalovich 2005; Singh 2011);

- If adults and pupils believe that there is nothing that can be done (eg cognitive deficit or poor parenting) this can result in abdication of responsibility (Arcia et al. 2000; Hands 2010; Houghton et al. 2006; Hughes 2007; Reid et al. 1996; Singh 2011);

- The failure of staff and parents to agree on an approach to intervention is a 'fundamental barrier to positive change', exacerbating problems and symptoms of ADHD through patterns of blame or by ignoring wider factors (Arcia et al. 2000; Brice 1998; Cooper and Shea 1998; Houghton et al. 2006; Hughes 2007; Prosser 2006; Singh 2011); 
- The failure for adults to agree on an intervention can leave pupils feeling helpless and frustrated, and adults' belief that medication is a powerful and effective intervention for ADHD without consideration of other strategies can impact pupil self-perceptions negatively, encouraging pupils to understand that they have no control over their behaviour (Cooper and Shea 1998; Exley 2008; Friio 1999; Hughes 2007; Kendall et al. 2003; Lee 2008; Ljusberg 2011; Prosser 2006; Singh 2011).

Some included studies explained polarised biological attributions through social trends toward medicalisation (Malacrida 2001; Rafalovich 2005) and polarised social attributions of poor parenting to cultural tendencies for mother blame (Carpenter and Austin 2008; Malacrida 2001). In addition, we suggest a lack of attributions to school contexts is at least partly a result of the school's role as the social group who determine that symptoms of ADHD are an 'undesired differentness' worthy of stigmatisation. This would explain the invisibility of school factors in teacher and pupil attributions for ADHD, because criteria for discrimination on the basis of stigma are implicit and appear normal and right to members of the group.

\section{Discussion}

This systematic review of qualitative research synthesises findings from primary research exploring individual experiences of ADHD within schools, drawing from sociological theories of stigma to further theorise the influence of school context on ADHD. Our synthesis of 34 studies suggests that, despite existing knowledge about the potential for school contexts to contribute to symptoms of $\mathrm{ADHD}$, teachers and pupils themselves may be blinded to the role of the school because criteria for discrimination on the basis of stigma are implicit and appear normal and right to members of the group. This lack of understanding may exacerbate the expression of symptoms of ADHD and contribute to emotional distress for those 
stigmatised. Furthermore, recognition of such potential influences of the school context may enhance attempts to implement school based interventions.

These findings suggest that lack of knowledge is an important difficulty faced by both school practitioners and pupils in response to ADHD symptoms. If stigma is invisible to those evoking it, teacher education is an obvious element needed for change. Many included studies identified a lack of teacher knowledge about ADHD (Arcia et al. 2000; Hands 2010; Hillman 2011; Hong 2008; Houghton et al. 2006; Lee 2008; Ljusberg 2011; Malacrida 2001; Nowacek and Mamlin 2007; Reid et al. 1996), and one study suggested that teachers felt less threatened by ADHD-related behaviour once they had been taught strategies to alleviate it in the classroom (Houghton et al. 2006). Teacher education and continuing professional development could establish the conceptual basis for teachers to make interactional attributions to explain symptoms of ADHD, where they consider individual pupil characteristics in interaction with classroom expectations and relationships, instead of focusing on pupil or family characteristics. Particularly salient seemed to be the need to explore individual pupil needs and motivations in relation to the classroom in order to understand the reasons behind a pupil's behaviour and how to manage it.

At the same time, an increase in knowledge about stigma for ADHD is not necessarily adequate to reduce it, with a review of stigma levels for mental illness over the past 40 years finding stigma had increased in some ways despite greater societal understanding, and with interventions intended to reduce stigma producing unanticipated effects (Pescosolido et al. 2008). The authors explained such complexities through a model of stigma involving multiple normalising influences, the Framework Integrating Normative Influences in Stigma (FINIS) (Pescosolido et al. 2008). This model posits that stigma results from interactions between the stigmatised, the stigmatiser, disease characteristics, social characteristics, media context, social network characteristics, the treatment system and the national context. Such 
complexity of factors are suggested by this review to be relevant to stigma for ADHD in schools, and interventions addressing symptoms of ADHD would benefit from inclusion of consideration of multiple factors in their design and delivery. For example, educational policy and legislation establish criteria by which schools and teachers are judged, and can support exclusionary practices (e.g. see Slee 2013).

\section{Strengths and limitations}

This synthesis was limited by the differences between studies, where underpinning theory and/or approaches to data collection were widely divergent. In such cases assumptions were made about links between unrelated studies. However, we were able to translate study findings across countries about the experience of ADHD in schools for multiple participant types, and we found theories of stigma to be particularly useful in doing so.

As is true for qualitative studies, this review does not claim to generally represent people's school-based experiences and perceptions of ADHD. Rather we claim credibility of the studies on the basis of designs incorporating approaches like member checks; we also claim the potential for transferability based on consultation with the review Steering Group and our experiences of stakeholder engagement during the project. As there are a range of differences in perceptions and experience expressed in different contexts, transferability is likely to be important, where the reader judges the relevance of findings according to their knowledge of a particular context.

\section{Conclusion}

This systematic review of qualitative research about the experience of ADHD in schools suggests that adaptations to the school classroom environment, routines and expectations, including support for relationships between pupils and their teachers and peers, are 
potentially valuable areas for exploration in future research about non-pharmacological interventions for ADHD in schools. The operation of stigma in this context is an important factor to be taken into account, with teacher education as well as support at institutional and national levels implicated in order for teachers to be able to change their routines and perceptions sufficiently to be inclusive to pupils displaying symptoms of ADHD.

\section{References}

APA. 1980. Diagnostic and Statistical Manual of Mental Disorders (3rd ed.). Washington DC: American Psychiatric Association.

APA. 2013. Diagnostic and Statistical Manual of Mental Disorders (5th Edition). Washington, DC: American Psychiatric Association.

Arcia, Emily, Rebecca Frank, Arturo Sanchez-LaCay, and Maria C. Fernandez. 2000.

"Teacher understanding of ADHD as reflected in attributions and classroom strategies." Journal of Attention Disorders 4 (2):91-101. doi: http://dx.doi.org/10.1177/108705470000400203.

Bailey, Simon, and Pat Thomson. 2009. "Routine (dis)order in an infant school." Ethnography and Education 4 (2):211-227.

Barkley, RA. 1990. Attention-deficit hyperactivity disorder: A handbook for diagnosis and treatment. New York: Guilford Press.

Brice, Patric J. 1998. "The experience of learning for youth diagnosed with attention deficit hyperactivity disorder." Dissertation Abstracts International: Section B: The Sciences and Engineering 58 (12-B):6801.

Campbell, R, P Pound, M Morgan, G Daker-White, N Britten, R Pill, and et al. 2011. "Evaluating meta-ethnography: systematic analysis and synthesis of qualitative research." Health Technology Assessment 15. doi: doi: 10.3310/hta15430.

Carpenter, Lorelei, and Helena Austin. 2008. "How to Be Recognized Enough to Be Included?" International Journal of Inclusive Education 12 (1):35-48.

Coghill, D. 2004. "Use of stimulants for attention deficit hyperactivity disorder." British Medical Journal 329 (7471):907-908.

Cooper, Paul, and Trevor Shea. 1998. "Pupils' perceptions of AD/HD." Emotional \& Behavioural Difficulties 3 (3):36-48. doi: http://dx.doi.org/10.1080/1363275980030306. 
CRD. 2009. Systematic Reviews: CRD's guidance for undertaking reviews in healthcare.

York: Centre for Reviews and Dissemination.

DuPaul, G, TL Eckert, and B Vilardo. 2012. "The Effects of School-Based Interventions for Attention Deficit Hyperactivity Disorder: A Meta-Analysis 1996-2010." SPR 41:387412.

Edwards, K. 2008. "The learning experiences and preferred educational strategies of children who have been identified as gifted with ADHD." Australasian Journal of Gifted Education 17 (2):15-22.

Einarsdottir, Johanna. 2008. "Teaching children with ADHD: Icelandic early childhood teachers' perspectives." Early Child Development and Care 178 (4):375-397. doi: http://dx.doi.org/10.1080/03004430701321696.

Evans SW, Owens JS, and Bunford N. 2014. "Evidence-based psychosocial treatments for children and adolescents with attention-deficit/hyperactivity disorder. " Journal of Clinical Child \& Adolescent Psychology 43 (4): 527-551.

Exley, B. 2006. " The behaviour 'crisis': young children's mis/understandings of the identities of ADHD."

Exley, B. 2007. " Young children's mis/understandings of the ADHD label." Educating Young Children 13 (1):38-40.

Exley, B. 2008. " "Staying in Class so No One Can Get to Him": A Case for the Institutional Reproduction of ADHD Categories and Behaviours." International Journal of Inclusive Education 12 (1):65-80.

Friio, Sam S. 1999. " The experiences of adolescents with ADHD: A phenomenological study." Dissertation Abstracts International Section A: Humanities and Social Sciences 59 (12-A):4357.

Goffman, E. 1990. Stigma: Notes on the Management of Spoiled Identity. Englewood Cliffs, NJ: Prentice-Hall Inc.

Guevara, James P., Chris Feudtner, Daniel Romer, Thomas Power, Ricardo Eiraldi, Snejana Nihtianova, Aracely Rosales, Janet Ohene-Frempong, and Donald F. Schwarz. 2005. "Fragmented care for inner-city minority children with attention-deficit/hyperactivity disorder." Pediatrics 116 (4):e512-7.

Gwernan-Jones, R., Moore, D.A., Garside, R., Richardson, M., Thompson-Coon, J., Rogers, M., Cooper, P., Stein, K. and Ford, T. (2015) “ADHD, parent perspectives and parent-teacher relationships: grounds for conflict”. British Journal of Special Education. doi: 10.1111/1467-8578.12087. 
Hands, Robin E. 2010. "The phenomenon of underachievement: Listening to the voice of a twice exceptional adolescent." Dissertation Abstracts International Section A: Humanities and Social Sciences 70 (9-A):3351.

Heider, F. 1958. The Psychology of Interpersonal Relations. New York, NY: Wiley.

Hibbitts, Patricia. 2010. "We do this for the next child: A mother's phenomenological auto narrative inquiry into experiencing her children's schools." Dissertation Abstracts International Section A: Humanities and Social Sciences 71 (4-A):1152.

Hillman, Mary Katherine. 2011. " An examination of teachers' recommendations for children with ADHD." Dissertation Abstracts International: Section B: The Sciences and Engineering 72 (1-B):535.

Hong, Yonghee. 2008. " Teachers' perceptions of young children with ADHD in Korea." Early Child Development and Care 178 (4):399-414. doi: http://dx.doi.org/10.1080/03004430701321829.

Houghton, S., A Carroll, M. Taylor, and T. O'Donoghue. 2006. From Traditional to Ecological: Understanding Attention Deficit Disorders Through Quantitative and Qualitative Research. New York, NY: Nova Science Publishers.

Hughes, Lesley A. 2007. " The reality of living with AD/HD: children's concern about educational and medical support." Emotional and Behavioural Difficulties 12 (1):6980 .

Husk, K, R Lovell, C Cooper, and R. . : . Garside. 2013. Intervention protocol: participation in environmental enhancement and conservation for health and well-being in adults.

Jones, Danna Benefield. 2008. " Phenomenological study: What are pre-kindergarten teachers' lived experiences with children identified with conduct disorder, oppositional defiance disorder, and attention-deficit hyperactivity disorder in the southeastern United States?" Dissertation Abstracts International Section A: Humanities and Social Sciences 69 (5-A):1663.

Kendall, Judy, Diane Hatton, Ann Beckett, and Michael Leo. 2003. "Children's Accounts of Attention-Deficit/Hyperactivity Disorder." Advances in Nursing Science 26:114-130. Koro-Ljungberg, Mirka, Regina Bussing, JeffriAnne Wilder, and Faye Gary. 2011. " Role of Communication in the Context of Educating Children with AttentionDeficit/Hyperactivity Disorder: Parents' and Teachers' Perspectives." Journal of School Public Relations 32 (1):41-75. 
Lee, Kyunghwa. 2008. " ADHD in American early schooling: From a cultural psychological perspective." Early Child Development and Care 178 (4):415-439. doi: http://dx.doi.org/10.1080/03004430701321852.

Ljusberg, Anna-Lena. 2011. " The Structured Classroom." International Journal of Inclusive Education 15 (2):195-210.

Malacrida, C. 2001. "Motherhood, resistance and attention deficit disorder: Strategies and limits." Canadian Review of Sociology and Anthropology-Revue Canadienne De Sociologie Et D Anthropologie 38 (2):141-165.

Malacrida, C. 2004. "Medicalization, ambivalence and social control: mothers' descriptions of educators and ADD/ADHD." Health: an Interdisciplinary Journal for the Social Study of Health, Illness \& Medicine 8 (1):61-80.

Margalit, Malka, Marshall H. Raskind, Eleanor L. Higgins, and Pninit Russo-Netzer. 2010. " Mothers' Voices on the Internet: Stress, Support and Perceptions of Mothers of Children with Learning Disabilities and Attention Deficit/Hyperactivity Disorder." Learning Disabilities: A Multidisciplinary Journal 16 (1):3-14.

McDannel, Renee Paula. 2005. " Classroom occupations from the perspectives of three high school students with attention deficit disorder." Dissertation Abstracts International Section A: Humanities and Social Sciences 65 (7-A):2550.

McMahon, Samantha Elizabeth. 2012. " Doctors diagnose, teachers label : the unexpected in pre-service teachers' talk about labelling children with ADHD." International Journal of Inclusive Education 16 (3):249-264.

NICE. 2013. Attention deficit hyperactivity disorder: Diagnosis and management of ADHD in children, young people and adults. National Institute of Clinical Excellence.

Noblit, GW, and RD . : Sage Publications Hare, . . 1988. Meta-ethnography: Synthesizing qualitative studies. London: Sage Publications.

Nowacek, E. Jane, and Nancy Mamlin. 2007. " General Education Teachers and Students with ADHD: What Modifications Are Made?" Preventing School Failure 51 (3):2835.

O’Regan, F. 2009. "A review of SENCo and GP attitudes towards ADHD." ADHD in Practice 1:4-7.

Pajo, B, and D Cohen. 2012. "The Problem with ADHD: Researchers' Constructions and Parents’ Accounts." IJEC:1-23. doi: doi: 10.1007/s13158-012-0064-z.

Pearson, A. 2004. "Balancing the evidence: incorporating the synthesis of qualitative data into systematic review." JBI Reports 2:45-64. 
Pelham, W. E., Jr., and G. A. Fabiano. 2008. "Evidence-based psychosocial treatments for attention-deficit/hyperactivity disorder." J Clin Child Adolesc Psychol 37 (1):184214. doi: 10.1080/15374410701818681.

Pescosolido, B. A., J. K. Martin, A. Lang, and S. Olafsdottir. 2008. "Rethinking theoretical approaches to stigma: a Framework Integrating Normative Influences on Stigma (FINIS)." Soc Sci Med 67 (3):431-40. doi: 10.1016/j.socscimed.2008.03.018.

Petticrew, M, and H Roberts. 2006. Systematic Reviews in the Social Sciences. Malden, MA: Blackwell Publishers.

Popay, J, H Roberts, A Sowden, M Petticrew, L Arai, M Rodgers, and et al. 2006. Guidance on the conduct of narrative synthesis in systematic reviews.

Prosser, B. 2006. Seeing Red: Critical narrative in ADHD research. Tenerife: Post Pressed.

Purdie, N., J. Hattie, and A. Carroll. 2002. "A Review of the Research on Interventions for Attention Deficit Hyperactivity Disorder: What Works Best?" Review of Educational Research 72 (1):61-99. doi: doi:10.3102/00346543072001061.

Rafalovich, Adam. 2005. " Relational Troubles and Semiofficial Suspicion: Educators and the Medicalization of "Unruly" Children." Symbolic Interaction 28 (1):25-46. doi: http://dx.doi.org/10.1525/si.2005.28.1.25.

Richardson, M. et al. (2015). 'Non pharmacological interventions for Attention Deficit Hyperactivity Disorder (ADHD) delivered in school settings: systematic reviews of quantitative and qualitative research', Health Technology Assessment, No. 19.45. doi: $10.3310 /$ hta19450

Reid, R., M. Hertzog, and M. Snyder. 1996. " Educating every teacher, every year: the public schools and parents of children with ADHD." Seminars in Speech \& Language 17 (1):73-90.

Shea, Barbara, and Judith Wiener. 2003. " Social Exile: The Cycle of Peer Victimization for Boys with ADHD." Canadian Journal of School Psychology 18 (1-2):55-90. doi: http://dx.doi.org/10.1177/082957350301800104.

Singh, Ilina. 2011. " A disorder of anger and aggression: children's perspectives on attention deficit/hyperactivity disorder in the UK." Social Science \& Medicine 73 (6):889-96.

Slee, R. 2013. "How do we make inclusive education happen when exclusion is a political predisposition? ." International Journal of Inclusive Education 17 (8):895-907.

Smithson, J, R Garside, and M Pearson. 2011. "Barriers to, and facilitators of, the prevention of unintentional injury in children in the home: a systematic review and synthesis of qualitative research." Inj Prev 17:119-26. doi: doi: 10.1136/ip.2010.026989. 
Sonuga-Barke, E. J., D. Brandeis, S. Cortese, D. Daley, M. Ferrin, M. Holtmann, J. Stevenson, M. Danckaerts, S. van der Oord, M. Dopfner, R. W. Dittmann, E. Simonoff, A. Zuddas, T. Banaschewski, J. Buitelaar, D. Coghill, C. Hollis, E. Konofal, M. Lecendreux, I. C. Wong, and J. Sergeant. 2013. "Nonpharmacological interventions for ADHD: systematic review and meta-analyses of randomized controlled trials of dietary and psychological treatments." Am J Psychiatry 170 (3):275-89. doi: 10.1176/appi.ajp.2012.12070991.

Taylor, Myra, and Stephen J. Houghton. 2008. " Difficulties in initiating and sustaining peer friendships: perspectives on students diagnosed with AD/HD." British Journal of Special Education 35 (4):209-219.

Thornicroft, G. 2006. Shunned: discrimination against people with mental illness. Oxford: Oxford University Press.

Wallace, A, K Croucher, D Quilgars, and S Baldwin. 2004. "Meeting the challenge: Developing systematic reviewing in social policy." Policy \& Politics 32 (4):455-470. Watson, Cate. 2011. " Home-school partnership and the construction of deviance: Being and becoming the Goldfish family." Journal of Research in Special Educational Needs 11 (1):20-29. doi: http://dx.doi.org/10.1111/j.1471-3802.2010.01183.x.

Weiner, B. 1985. "An Attributional Theory of Achievement Motivation and Emotion." Psychological Review 92 (4):548-573.

Wolfberg, Pamela J., Craig Zercher, Joan Lieber, Karen Capell, Sonya Matias, Marci Hanson, and Samuel L. Odom. 1999. " "Can I play with you?" Peer culture in inclusive preschool programs." Journal of the Association for Persons with Severe Handicaps 24 (2):69-84. doi: http://dx.doi.org/10.2511/rpsd.24.2.69.

Wolraich, M., L. Brown, R. T. Brown, G. DuPaul, M. Earls, H. M. Feldman, T. G. Ganiats, B. Kaplanek, B. Meyer, J. Perrin, K. Pierce, M. Reiff, M. T. Stein, and S. Visser. 2011. "ADHD: clinical practice guideline for the diagnosis, evaluation, and treatment of attention-deficit/hyperactivity disorder in children and adolescents." Pediatrics 128 (5):1007-22. doi: 10.1542/peds.2011-2654. 
Table 1. Number of included studies by participant type

\begin{tabular}{|c|c|c|}
\hline Participant group types & No. of included studies & Papers \\
\hline $\begin{array}{l}\text { a. The school experiences and } \\
\text { perceptions of pupils diagnosed with } \\
\text { ADHD (Pupil views) }\end{array}$ & $\begin{array}{c}11^{\mathrm{a}} \text { studies reported in } \\
13 \text { papers }\end{array}$ & $\begin{array}{l}\text { (Brice 1998, Cooper and Shea 1998, Exley 2006, } \\
\text { 2007, 2008, Friio 1999, Houghton et al. 2006, } \\
\text { Kendall et al. 2003, McDannel 2005, Prosser 2006, } \\
\text { Singh 2011, Taylor and Houghton 2008, Wolfberg et } \\
\text { al. 1999) }\end{array}$ \\
\hline $\begin{array}{l}\text { b. The school experiences and } \\
\text { perceptions of teachers of pupils } \\
\text { diagnosed with or at risk of ADHD } \\
\text { (Teacher views) }\end{array}$ & $11^{\mathrm{a}}$ & $\begin{array}{l}\text { (Arcia et al. 2000, Bailey and Thomson 2009, } \\
\text { Einarsdottir 2008, Hillman 2011, Hong 2008, } \\
\text { Houghton et al. 2006, Jones 2008, Lee 2008, } \\
\text { Ljusberg 2011, McMahon 2012, Nowacek and } \\
\text { Mamlin 2007) }\end{array}$ \\
\hline $\begin{array}{l}\text { c. The school experience and perceptions } \\
\text { of parents of pupils diagnosed with or at } \\
\text { risk of ADHD (Parent views) }\end{array}$ & $\begin{array}{c}6 \text { studies reported in } 7 \\
\text { papers }\end{array}$ & $\begin{array}{l}\text { Carpenter and Austin 2008, Hibbitts 2010, } \\
\text { Malacrida 2001, 2004, Margalit et al. 2010, Reid, } \\
\text { Hertzog, and Snyder 1996, Watson 2011) }\end{array}$ \\
\hline $\begin{array}{l}\text { d. The school experiences and } \\
\text { perceptions of pupils diagnosed with or at } \\
\text { risk of ADHD, their teachers, parents and } \\
\text { peers (Mixed views) }\end{array}$ & 7 & $\begin{array}{l}\text { (Edwards 2008, Guevara et al. 2005, Hands } 2010 \text {, } \\
\text { Hughes 2007, Koro-Ljungberg et al. 2011, } \\
\text { Rafalovich 2005, Shea and Wiener 2003) }\end{array}$ \\
\hline Overarching synthesis & $34^{\mathrm{a}}$ & \\
\hline
\end{tabular}

a One study (Houghton et al. 2006) contributed to two sub-reviews (pupil views and teacher views). 
Table 2. Relationships between reviewer findings and included studies

Reviewer findings from participant group subsyntheses
Overarching theme: The influence of school context on symptoms of ADHD

\begin{tabular}{llll}
\hline $\begin{array}{l}\text { School context and } \\
\text { the aggravation of }\end{array}$ & $\begin{array}{l}\text { Constituting deviance } \\
\text { and invoking stigma }\end{array}$ & $\begin{array}{l}\text { The relationship } \\
\text { between stigma and } \\
\text { attributions for }\end{array}$ & Contributing studies \\
& & ADH symptoms &
\end{tabular}

ADHD

a. Pupil views: Expression of symptoms in pupils diagnosed with ADHD as an interaction of biological, sociological and psychological factors

\section{Experience of ADHD}

symptoms

X

X

Relationships, classroom

context and stigma

X

$\mathrm{X}$

Identity, agency and desire

for approval

X

X

Impact of polarised

attributions about ADHD
(Brice 1998; Cooper and Shea 1998; Friio

1999; Houghton et al. 2006; Kendall, Hatton, Beckett, and Leo 2003; McDannel 2005; Prosser 2006; Singh 2011)

(Brice 1998; Cooper and Shea 1998; Exley 2008; Friio 1999; Houghton et al. 2006; Kendall et al. 2003; McDannel 2005;

Prosser 2006; Singh 2011; Taylor and Houghton 2008; Wolfberg et al. 1999) (Cooper and Shea 1998; Exley 2008; Friio 1999; Houghton et al. 2006; Kendall et al. 2003; McDannel 2005; Prosser 2006; Singh 2011; Taylor and Houghton 2008)

(Cooper and Shea1998; Exley 2008;

X Kendall et al. 2003; Prosser 2006; Singh 2011)

b. Teacher views: Factors that influence teachers' willingness to adapt their response to ADHD symptoms Orientation to the class vs the individual

$\mathrm{X}$

Perceptions of ADHD

behaviour

$\mathrm{X}$

c. Parent views: Mothers are silenced

Dashed expectations

$\mathrm{X}$

Parent-teacher conflict

X

Resistance

d. Mixed views: Relationships between participant groups: Foundations for conflict

Fit between pupils diagnosed

with ADHD and school

Orientation to the class vs.

the individual

Different funds of knowledge

Processes of collaboration
(Arcia et al. 2000; Einarsdottir 2008; Hillman 2011; Hong 2008; Houghton et al. 2006; Jones 2008; Lee 2008; Ljusberg 2011; McMahon 2012; Nowacek and Mamlin 2007)

(Arcia et al. 2000; Bailey and Thomson 2009; Einarsdottir 2008; Hillman 2011; Hong 2008; Houghton et al. 2006; Jones 2008; Lee 2008; Ljusberg 2011; McMahon 2012; Nowacek and Mamlin 2007)

(Carpenter and Austin 2008; Hibbitts 2010; Malacrida 2001)

(Hibbitts 2010; Malacrida 2001; Margalit et al. 2010; Reid et al. 1996; Watson 2011) (Carpenter and Austin 2008; Hibbitts 2010; Malacrida 2001; Reid et al., 1996; Watson 2011)

(Edwards 2008; Hands 2010; Rafalovich 2005; Shea and Wiener 2003)

(Hands 2010)

(Hughes 2007; Koro-Ljungberg et al. 2011; Rafalovich 2005)

(Guevara et al. 2005; Koro-Ljungberg et al. 2011) 


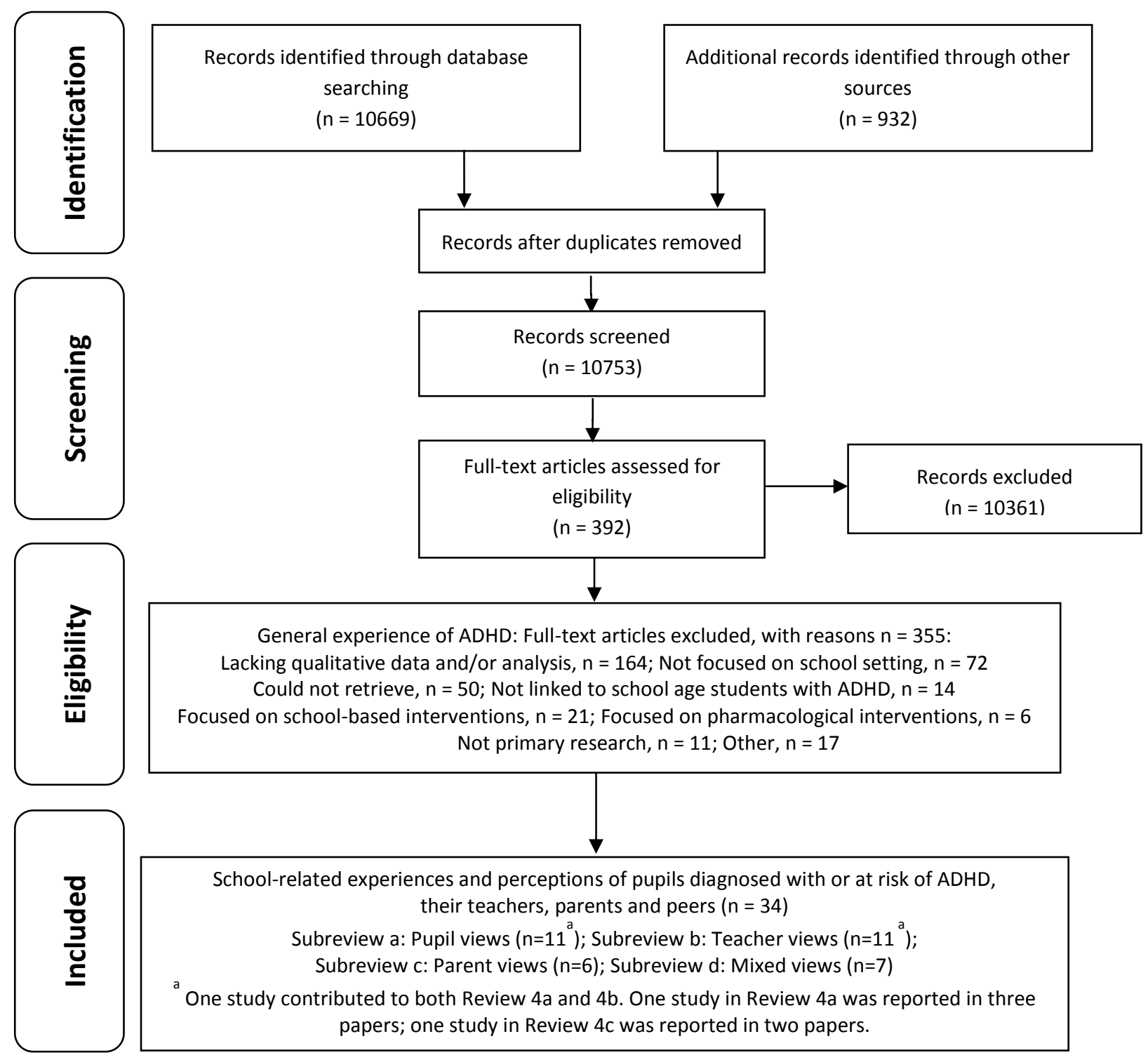

Figure 1. Diagram reporting the process of study selection 


\section{Supplementary Table 1. Quality appraisal questions}

1. Is the research question clear?

2. Is the theoretical or ideological perspective of the author explicit?

3. Has the theoretical or ideological perspective influenced the study design, methods or research findings?

4. Is the study design appropriate to answer the question?

5. Is the context or setting adequately described?

6. Is the sample adequate to explore the range of subjects and settings, and has it been drawn from an appropriate population?

7. Was the data collection adequately described?

8. Was data collection rigorously conducted to ensure confidence in the findings?

9. Was there evidence that the data analysis was rigorously conducted to ensure confidence in the findings?

10. Are the findings substantiated by the data?

11. Has consideration been given to any limitations of the methods or data that may have affected the results?

12. Do any claims to generalizability follow logically and theoretically from the data?

13. Have ethical issues been addressed and confidentiality respected?

14. Is the author reflexive? 
Supplementary Table 2. Number of participants by subreview, study and participant type

\begin{tabular}{|c|c|c|c|c|c|c|c|c|c|c|c|c|c|}
\hline \multirow[t]{3}{*}{ Study } & \multicolumn{5}{|c|}{ Pupils diagnosed or at risk of ADHD } & \multicolumn{5}{|c|}{ Teachers } & \multicolumn{3}{|c|}{ Parents } \\
\hline & \multicolumn{3}{|c|}{ No. Gender } & \multicolumn{2}{|l|}{ Age } & \multirow[t]{2}{*}{ No. } & \multirow{2}{*}{$\begin{array}{l}\text { No. } \\
\text { teaching } \\
\text { aged 3-6 }\end{array}$} & \multirow{2}{*}{$\begin{array}{l}\text { No. } \\
\text { teaching } \\
\text { ages 6-11 }\end{array}$} & \multirow{2}{*}{$\begin{array}{l}\text { No. } \\
\text { teaching } \\
\text { ages 11- } \\
18\end{array}$} & \multirow{2}{*}{$\begin{array}{l}\text { No. of } \\
\text { special } \\
\text { educational } \\
\text { needs } \\
\text { teachers }\end{array}$} & \multirow[t]{2}{*}{ No. } & \multicolumn{2}{|l|}{ Gender } \\
\hline & & Male & Female & $\begin{array}{l}\text { Preschool- } \\
\text { Primary } \\
\text { (aged 4-11) }\end{array}$ & $\begin{array}{l}\text { Secondary- } \\
\text { College } \\
\text { (aged 11-18) }\end{array}$ & & & & & & & Mother & Father \\
\hline \multicolumn{14}{|l|}{ Pupil views } \\
\hline Brice (1998) & 10 & 9 & 1 & & 10 (aged 13-18) & & & & & & & & \\
\hline Cooper and Shea (1998) & 16 & 10 & 6 & & 16 (aged 11-16) & & & & & & & & \\
\hline Exley (2008) & 2 & 2 & & 2 (aged 8-9) & & & & & & & & & \\
\hline Friio (1999) & 5 & 5 & & & 5 (aged 14-18) & & & & & & & & \\
\hline McDannel (2005) & 3 & 3 & & & 3 (aged 17) & & & & & & & & \\
\hline Prosser (2006) & 11 & 11 & & & 11 (aged 14-16) & & & & & & & & \\
\hline Wolfberg et al. (1999) & 1 & 1 & & 1 (age 4-5) & & & & & & & & & \\
\hline Houghton et al. (2006) & 20 & 14 & 6 & 9 (aged 6-11) & 11 (aged 11-17) & & & & & & & & \\
\hline Taylor and Houghton (2008) & 15 & 13 & 2 & 5 (mean age 9 ) & 10 (mean age 14$)$ & & & & & & & & \\
\hline Pupil view subtotals ${ }^{\mathrm{a}}$ & 83 & 68 & 15 & & 66 & & & & & & & & \\
\hline Kendall $(2003)^{\mathrm{b}}$ & 39 & 26 & 13 & 39 (age 6-17, me & $11.2)$ & & & & & & & & \\
\hline Singh $(2011)^{c}$ & $100^{\mathrm{d}}$ & $\mathrm{n} / \mathrm{r}^{\mathrm{e}}$ & $\mathrm{n} / \mathrm{r}$ & 100 (age 9-14) & & & & & & & & & \\
\hline Pupil view totals & 222 & 94 & 28 & & & & & & & & & & \\
\hline \multicolumn{14}{|l|}{$\begin{array}{l}\text { Teacher views } \\
\text { niew }\end{array}$} \\
\hline Arcia et al. (2000) & & & & & & 21 & 3 & 16 & 1 & 1 & & & \\
\hline Bailey and Thompson (2009) & & & & & & 4 & 4 & & & & & & \\
\hline Einarsdottir (2008) & & & & & & 16 & 8 & 8 & & & & & \\
\hline Hong (2008) & & & & & & 23 & 10 & 12 & & 1 & & & \\
\hline Houghton et al. (2006) & & & & & & 36 & & & 36 & & & & \\
\hline Jones (2008) & & & & & & 20 & 20 & & & & & & \\
\hline Lee (2008) & & & & & & 8 & 2 & 6 & & & & & \\
\hline Ljusberg (2011a) & & & & & & 10 & & & & 10 & & & \\
\hline Nowacek and Mamlin (2007) & & & & & & 8 & & 3 & 5 & & & & \\
\hline Teacher view subotals & & & & & & 146 & 47 & 45 & 42 & 12 & & & \\
\hline Hillman $(2011)^{\mathrm{f}}$ & & & & & & 38 & Kindergart & ten to Grade & & & & & \\
\hline McMahon $(2012)^{\mathrm{f}}$ & & & & & & 150 & Pre-service & e teachers & & & & & \\
\hline Teacher view totals & & & & & & 334 & & & & & & & \\
\hline
\end{tabular}




\begin{tabular}{|c|c|c|c|c|c|c|c|c|c|c|}
\hline No. Gender & & Age & & No. & No. & & & No. of & No. & Gender \\
\hline Male & Female & $\begin{array}{l}\text { Preschool- } \\
\text { Primary } \\
\text { (aged 4-11) }\end{array}$ & $\begin{array}{l}\text { Secondary- } \\
\text { College } \\
\text { (aged 11-18) }\end{array}$ & & aged 3-6 & ages 6-11 & $\begin{array}{l}\text { ages } 11- \\
18\end{array}$ & $\begin{array}{l}\text { educational } \\
\text { needs } \\
\text { teachers }\end{array}$ & & Mother \\
\hline
\end{tabular}

Parent views

Carpenter and Austin (2008)

Hibbitts (2010)

Malacrida (2001; 2004)

Margalit et al. (2010)

Reid et al. (1996)

Watson (2011)

Parent view totals

\begin{tabular}{lll}
15 & 15 & \\
1 & 1 & \\
34 & 34 & \\
168 & $168 \mathrm{~g}$ & \\
20 & 18 & 2 \\
1 & 1 & \\
239 & 237 & 2 \\
\hline
\end{tabular}

Mixed views

Edwards (2008)

Hands (2009)

Shea and Wiener (2003)

Koro-Ljungberg et al. (2012)

Mixed view subotals

Rafalovich (2004)

Hughes (2007)

Mixed view Totals

Guevara et al. (2005)

$\begin{array}{llll}6 & 4 & 2 & 6 \\ 1 & 1 & 0 & 0 \\ 4 & 4 & 0 & 0 \\ 11 & 9 & 2 & 6 \\ 14 & 14 & 0 & 14(\text { aged } 7-12) \\ 25 & 23 & 2 & \end{array}$

Totals

$\begin{array}{llll}258 & 117 & 30 & 23\end{array}$

$23 \quad 71$

$\begin{array}{lll}71 & 389 & 47\end{array}$

$389 \quad 47 \quad 45$ $45 \quad 56$ $56 \quad 13$ 13 $302 \quad 272$

b totals=cumulative totals for studies where information is reported
Path participants across Primary and Secondary levels reporting gender

c Paper with participants across Primary and Secondary levels not reporting gender

d Comprised by three groups: 1) those diagnosed with ADHD who are medicated;2) those diagnosed with ADHD who are not medicated; 3) those without ADHD diagnosis or

symptoms; 100 pupils diagnosed with ADHD is based on an assumption of equal group category size.

$\mathrm{e} / \mathrm{r}=$ not reported

f papers that do not report age ranges of children taught

g: Mothers of children diagnosed with ADHD (44), ADHD and learning difficulties (LD) (124), LD (148) 
Supplementary Table 3. Included study characteristics and methods

\begin{tabular}{|c|c|c|c|c|c|c|c|}
\hline $\begin{array}{l}\text { Study and } \\
\text { location }\end{array}$ & $\begin{array}{l}\text { Sample } \\
\text { Size }\end{array}$ & $\begin{array}{l}\text { Sample } \\
\text { characteristics }\end{array}$ & Data collectiona & Sampling & Study Aims & Theoretical approach & Data analysis \\
\hline \multicolumn{8}{|c|}{ Pupils diagnosed with ADHD } \\
\hline $\begin{array}{l}\text { Brice (1998) } \\
\text { USA }\end{array}$ & 10 & $\begin{array}{l}9 \text { males; } 1 \text { female } \\
\text { aged } 13-18\end{array}$ & $10 \mathrm{SSI}$ & $\begin{array}{l}\text { Convenience, } \\
\text { purposive }\end{array}$ & $\begin{array}{l}\text { To understand the perspectives of } \\
\text { young people diagnosed with } \\
\text { ADHD about learning }\end{array}$ & $\begin{array}{l}\text { Transcendental } \\
\text { Phenomenological }\end{array}$ & $\begin{array}{l}\text { Descriptive accounts and } \\
\text { structural analysis }\end{array}$ \\
\hline $\begin{array}{l}\text { Cooper and } \\
\text { Shea (1998) } \\
\text { UK }\end{array}$ & 16 & $\begin{array}{l}10 \text { males; } 6 \text { females } \\
\text { aged } 11-16\end{array}$ & $32 \mathrm{SSI}$ & $\begin{array}{l}\text { Convenience, } \\
\text { purposive }\end{array}$ & $\begin{array}{l}\text { To explore perceptions of pupils } \\
\text { diagnosed with ADHD: symptoms; } \\
\text { diagnostic label; treatment }\end{array}$ & $\begin{array}{l}\text { The impact of bio-psycho- } \\
\text { social vs. } \\
\text { individual/medical views }\end{array}$ & Content analysis \\
\hline $\begin{array}{l}\text { Exley (2008) } \\
\text { Australia }\end{array}$ & 2 & 2 males aged 8-9 & $\begin{array}{l}2 \text { SSI; O } \\
\text { (playground) }\end{array}$ & $\mathrm{n} / \mathrm{r}$ & $\begin{array}{l}\text { To understand the lived experience } \\
\text { of children diagnosed with ADHD } \\
\text { of social play }\end{array}$ & Critical ethnography & $\mathrm{n} / \mathrm{r}^{\mathrm{b}}$ \\
\hline $\begin{array}{l}\text { Friio (1999) } \\
\text { Canada }\end{array}$ & 5 & 5 males aged $14-18$ & $15 \mathrm{SSI}$ & $\begin{array}{l}\text { Convenience, } \\
\text { purposive }\end{array}$ & $\begin{array}{l}\text { To explore the experiences of } \\
\text { young people diagnosed with } \\
\text { ADHD }\end{array}$ & $\begin{array}{l}\text { Hermeneutic } \\
\text { Phenomenology }\end{array}$ & Thematic analysis \\
\hline $\begin{array}{l}\text { Houghton et al. } \\
\text { (2006)f } \\
\text { Australia }\end{array}$ & 20 & 14 males, 6 females & $20 \mathrm{SSI}$ & Purposive & $\begin{array}{l}\text { To explore how students deal with } \\
\text { anger arising from the stress of } \\
\text { living with ADHD }\end{array}$ & $\begin{array}{l}\text { Ecological validity; } \\
\text { symbolic interactionism } \\
\text { and Grounded Theory }\end{array}$ & $\begin{array}{l}\text { Constant comparative } \\
\text { method }\end{array}$ \\
\hline $\begin{array}{l}\text { Kendall (2003) } \\
\text { USA }\end{array}$ & 39 & $\begin{array}{l}26 \text { males, } 13 \\
\text { females aged 6-17 }\end{array}$ & $39 \mathrm{SSI}$ & Purposive & $\begin{array}{l}\text { To explore perceptions of ADHD in } \\
\text { a context of controversy }\end{array}$ & $\begin{array}{l}\text { Whether or not ADHD is } \\
\text { 'truly a bonafide } \\
\text { biological disease' }\end{array}$ & $\begin{array}{l}\text { Constant comparative } \\
\text { method }\end{array}$ \\
\hline $\begin{array}{l}\text { McDannel } \\
(2005) \\
\text { USA }\end{array}$ & 3 & 3 males aged 17 & $\begin{array}{l}24 \text { hours SSI; } 64 \\
\text { hours O } \\
\text { (classroom) }\end{array}$ & $\begin{array}{l}\text { Convenience, } \\
\text { self-selecting, } \\
\text { purposive }\end{array}$ & $\begin{array}{l}\text { To investigate student occupations } \\
\text { within the classroom for young } \\
\text { people diagnosed with ADHD }\end{array}$ & $\begin{array}{l}\text { Ethnography; theories } \\
\text { from occupational therapy }\end{array}$ & $\begin{array}{l}\text { Constant comparative } \\
\text { method }\end{array}$ \\
\hline $\begin{array}{l}\text { Prosser (2006) } \\
\text { Australia and } \\
\text { USA }\end{array}$ & 11 & 11 males aged $14-16$ & SSI; FG & $\begin{array}{l}\text { Purposive; self- } \\
\text { selecting }\end{array}$ & $\begin{array}{l}\text { To critically explore the impact of } \\
\text { understanding ADHD as an } \\
\text { individual biological deficit }\end{array}$ & Narrative Research & Critical cover narratives \\
\hline $\begin{array}{l}\text { Singh (2011) } \\
\text { UK and USA }\end{array}$ & 150 & $\begin{array}{l}\text { Males and females } \\
\text { aged 9-14 c }\end{array}$ & $\begin{array}{l}\text { SSI; Q; range of } \\
\text { activities }\end{array}$ & $\begin{array}{l}\text { Self-selecting; } \\
\text { purposive }\end{array}$ & $\begin{array}{l}\text { To uncover the social and moral } \\
\text { dimensions of ADHD diagnosis as } \\
\text { manifested in the interplay of self- } \\
\text { control, stigma and agency }\end{array}$ & $\begin{array}{l}\text { Use of Haimes' empirical } \\
\text { bioethics; Bronfenbrenner }\end{array}$ & $\begin{array}{l}\text { Inductive and deductive } \\
\text { thematic analysis }\end{array}$ \\
\hline $\begin{array}{l}\text { Taylor and } \\
\text { Houghton } \\
(2008) \\
\text { Australia }\end{array}$ & 15 & $\begin{array}{l}9 \text { males, } 1 \text { female } \\
\text { aged } 11-18 ; 4 \text { males, } \\
1 \text { female aged } 6-11\end{array}$ & 20 SSI (telephone) & $\begin{array}{l}\text { Self-selecting; } \\
\text { snowball }\end{array}$ & $\begin{array}{l}\text { To explore how students diagnosed } \\
\text { with AD/HD initiate and sustain } \\
\text { peer friendships }\end{array}$ & Symbolic Interactionism & Grounded Theory \\
\hline $\begin{array}{l}\text { Wolfberg et al. } \\
\text { (1999) } \\
\text { USA } \\
\text { Teachers of pupi }\end{array}$ & s diagnose & $\begin{array}{l}\text { One diagnosed with } \\
\text { ADHD (male age } \\
\text { 5)d } \\
\text { ith or at risk of } A D H D\end{array}$ & $\mathrm{O}$ & Purposive & $\begin{array}{l}\text { To explore how children with } \\
\text { disabilities experience peer culture }\end{array}$ & $\begin{array}{l}\text { Bronfenbrenner's theory } \\
\text { of ecological systems }\end{array}$ & $\begin{array}{l}\text { Constant comparative } \\
\text { method }\end{array}$ \\
\hline $\begin{array}{l}\text { Arcia et al. } \\
\text { (2000) } \\
\text { USA }\end{array}$ & 21 & $\begin{array}{l}3 \text { Kindergarten, } 18 \\
\text { Elementary School } \\
\text { teachers }\end{array}$ & $\begin{array}{l}42 \text { SSI (telephone); } \\
\text { rating scales }\end{array}$ & Purposive & $\begin{array}{l}\text { To describe teacher understanding } \\
\text { and strategies towards disruptive } \\
\text { behaviors }\end{array}$ & $\mathrm{n} / \mathrm{r}$ & Miles and Huberman \\
\hline $\begin{array}{l}\text { Bailey and } \\
\text { Thompson } \\
\text { (2009) }\end{array}$ & 4 & $\begin{array}{l}\text { Infant school } \\
\text { teachers }\end{array}$ & $\begin{array}{l}\mathrm{O} \text {; field notes over } \\
10 \text { weeks }\end{array}$ & $\mathrm{n} / \mathrm{r}$ & $\begin{array}{l}\text { To analyze everyday micro- } \\
\text { processes of the classroom in order } \\
\text { to deconstruct ADHD }\end{array}$ & $\begin{array}{l}\text { Ethnography; post- } \\
\text { structuralism }\end{array}$ & $\begin{array}{l}\text { Foucault's concepts of } \\
\text { discourse and power }\end{array}$ \\
\hline
\end{tabular}




\begin{tabular}{|c|c|c|c|c|c|c|c|}
\hline $\begin{array}{l}\text { Study and } \\
\text { location }\end{array}$ & $\begin{array}{l}\text { Sample } \\
\text { Size }\end{array}$ & $\begin{array}{l}\text { Sample } \\
\text { characteristics }\end{array}$ & Data collectiona & Sampling & Study Aims & Theoretical approach & Data analysis \\
\hline UK & & & & & & & \\
\hline $\begin{array}{l}\text { Einarsdottir } \\
(2008) \\
\text { Iceland }\end{array}$ & 16 & $\begin{array}{l}8 \text { Preschool, } 8 \text { Grade } \\
1 \text { teachers }\end{array}$ & $16 \mathrm{SSI}$ & $\mathrm{n} / \mathrm{r}$ & $\begin{array}{l}\text { To understand Icelandic early } \\
\text { childhood teachers' experiences and } \\
\text { perspectives of children with } \\
\text { ADHD-associated behavior }\end{array}$ & $\begin{array}{l}\text { Phenomenology with a } \\
\text { sociological lens }\end{array}$ & $\begin{array}{l}\text { Phenomenological } \\
\text { approach }\end{array}$ \\
\hline $\begin{array}{l}\text { Hillman (2011) } \\
\text { USA, UK, } \\
\text { Canada }\end{array}$ & 30 & $\begin{array}{l}\text { teachers } \\
\text { kindergarten to } \\
\text { Grade } 8\end{array}$ & $\begin{array}{l}\text { Online open-ended } \\
\text { questions followed } \\
\text { vignettes }\end{array}$ & Self-selecting & $\begin{array}{l}\text { To examine teachers' ability to } \\
\text { identify ADHD, their referral } \\
\text { recommendations, ethnicity and } \\
\text { gender }\end{array}$ & $\begin{array}{l}\text { Essentialist } \\
\text { epistemological stance }\end{array}$ & Thematic analysis \\
\hline $\begin{array}{l}\text { Houghton et al } \\
(2006) \mathrm{f} \\
\text { Australia }\end{array}$ & 36 & High school teachers & $36 \mathrm{SSI}$ & Purposive & $\begin{array}{l}\text { To explore how teachers deal with } \\
\text { the frustration triggered by some } \\
\text { students diagnosed with ADHD }\end{array}$ & $\begin{array}{l}\text { Ecological validity; } \\
\text { symbolic interactions and } \\
\text { Grounded Theory }\end{array}$ & $\begin{array}{l}\text { Constant comparative } \\
\text { method }\end{array}$ \\
\hline $\begin{array}{l}\text { Hong }(2008) \\
\text { Korea }\end{array}$ & 23 & $\begin{array}{l}\text { Teachers (preschool- } \\
\text { elementary), } \\
\text { occupational } \\
\text { therapist }\end{array}$ & $\begin{array}{l}7 \text { SSI; } 1 \text { FG; open- } \\
\text { ended survey }\end{array}$ & Purposive & $\begin{array}{l}\text { To investigate early childhood } \\
\text { teachers' beliefs about children with } \\
\text { ADHD }\end{array}$ & $\mathrm{n} / \mathrm{r}$ & $\mathrm{n} / \mathrm{r}$ \\
\hline $\begin{array}{l}\text { Jones (2008) } \\
\text { USA }\end{array}$ & 20 & Preschool teachers & $\begin{array}{l}20 \text { SSI, follow-up } \\
\text { telephone calls and } \\
\text { emails }\end{array}$ & $\begin{array}{l}\text { Convenience, } \\
\text { purposive }\end{array}$ & $\begin{array}{l}\text { To explore how pre-k teachers } \\
\text { handle children identified with CD, } \\
\text { ODD and ADHD to illuminate } \\
\text { strategies }\end{array}$ & $\begin{array}{l}\text { Principles of } \\
\text { phenomenology; } \\
\text { constructionism }\end{array}$ & Moustakas \\
\hline $\begin{array}{l}\text { Lee (2008) } \\
\text { USA }\end{array}$ & 10 & $\begin{array}{l}\text { pre-Kindergarten to } \\
\text { Elementary School } \\
\text { teachers. } 2 \text { teachers } \\
\text { per grade }\end{array}$ & $10 \mathrm{SSI}$ & $\mathrm{n} / \mathrm{r}$ & $\begin{array}{l}\text { To understand US teachers' } \\
\text { perceptions of problem behavior, } \\
\text { ADHD, diagnosis and medication } \\
\text { treatment, and how this reflects } \\
\text { cultural beliefs }\end{array}$ & $\begin{array}{l}\text { Socio-cultural theory; } \\
\text { cultural psychology }\end{array}$ & Thematic analysis \\
\hline $\begin{array}{l}\text { Ljusberg } \\
\text { (2011a) } \\
\text { Sweden }\end{array}$ & 10 & $\begin{array}{l}\text { Remedial teachers. } \\
\text { Years 3-5 }\end{array}$ & $10 \mathrm{SSI}$ & $\begin{array}{l}\text { Convenience and } \\
\text { purposive }\end{array}$ & $\begin{array}{l}\text { To highlight the physical and } \\
\text { mental environment in the remedial } \\
\text { classroom }\end{array}$ & $\begin{array}{l}\text { Socio-cultural theory; } \\
\text { Discourse analysis }\end{array}$ & Thematic analysis \\
\hline $\begin{array}{l}\text { McMahon } \\
(2012) \\
\text { Australia }\end{array}$ & 150 & Pre-service teachers & 150 Q ;6 SSI; 1 FG & $\mathrm{n} / \mathrm{r}$ & $\begin{array}{l}\text { To better understand pre-service } \\
\text { teachers' participation in discourses } \\
\text { of ADHD }\end{array}$ & $\begin{array}{l}\text { Constructionism; critical } \\
\text { approach, socio-cultural } \\
\text { theory; Foucauldian }\end{array}$ & $\begin{array}{l}\text { Thematic analysis, } \\
\text { discourse analysis }\end{array}$ \\
\hline $\begin{array}{l}\text { Nowacek and } \\
\text { Mamlin (2007) } \\
\text { USA }\end{array}$ & 8 & $\begin{array}{l}4 \text { Elementary } \\
\text { teachers: } 4 \text { Middle } \\
\text { school }\end{array}$ & $\begin{array}{l}\text { Open ended } \\
\text { question asking for } \\
\text { definition of } \\
\text { ADHD; } 8 \text { SSI; O } \\
\text { (classroom) } \\
\end{array}$ & Purposive & $\begin{array}{l}\text { To explore teacher understandings } \\
\text { of ADHD and strategies }\end{array}$ & Grounded Theory & $\begin{array}{l}\text { Constant comparative } \\
\text { method }\end{array}$ \\
\hline \multicolumn{8}{|c|}{ Parents of pupils diagnosed with $A D H D$} \\
\hline $\begin{array}{l}\text { Carpenter and } \\
\text { Austin (2008) } \\
\text { Australia }\end{array}$ & 15 & Mothers & 45 SSI, 1 FG & $\begin{array}{l}\text { Self-selecting; } \\
\text { purposive; } \\
\text { convenience }\end{array}$ & $\begin{array}{l}\text { To explore mother's perceptions of } \\
\text { the role of schools in decision- } \\
\text { making processes leading to } \\
\text { diagnosis and medication }\end{array}$ & Post-structural & Thematic analysis \\
\hline $\begin{array}{l}\text { Hibbitts (2010) } \\
\text { Canada }\end{array}$ & 1 & Mother & 48 vignettes & $\mathrm{n} / \mathrm{a}$ & $\begin{array}{l}\text { To explore the experience of a } \\
\text { parent interacting with her } \\
\text { children's schools }\end{array}$ & $\begin{array}{l}\text { Constructionism; } \\
\text { Phenomenology }\end{array}$ & $\begin{array}{l}\text { Auto-narrative using } \\
\text { Hermeneutic } \\
\text { phenomenology }\end{array}$ \\
\hline
\end{tabular}




\begin{tabular}{|c|c|c|c|c|c|c|c|}
\hline $\begin{array}{l}\text { Study and } \\
\text { location }\end{array}$ & $\begin{array}{l}\text { Sample } \\
\text { Size }\end{array}$ & $\begin{array}{l}\text { Sample } \\
\text { characteristics }\end{array}$ & Data collectiona & Sampling & Study Aims & Theoretical approach & Data analysis \\
\hline $\begin{array}{l}\text { Malacrida } \\
\text { (2001; 2004) } \\
\text { Canada and } \\
\text { UK }\end{array}$ & 34 & Mothers & 34 SSI & $\begin{array}{l}\text { Self-selecting; } \\
\text { snowball }\end{array}$ & $\begin{array}{l}\text { To investigate confronting multiple } \\
\text { "helping" professionals while } \\
\text { dealing with ADHD; to examine } \\
\text { maternal narratives about educators' } \\
\text { roles in the medicalization of their } \\
\text { children's behavior }\end{array}$ & $\begin{array}{l}\text { Constructionist; } \\
\text { Foucaultian; theories of } \\
\text { medicalization }\end{array}$ & Thematic analysis \\
\hline $\begin{array}{l}\text { Margalit et al. } \\
(2010) \\
\text { USA }\end{array}$ & $316 \mathrm{e}$ & Mothers & $\begin{array}{l}1,502 \text { internet } \\
\text { messages }\end{array}$ & Self-selecting & $\begin{array}{l}\text { To identify perceptions of mothers } \\
\text { of children with learning disabilities } \\
\text { and ADHD }\end{array}$ & $\mathrm{n} / \mathrm{r}$ & Content analysis \\
\hline $\begin{array}{l}\text { Reid et al. } \\
(1996) \\
\text { USA }\end{array}$ & 20 & $\begin{array}{l}18 \text { Mothers } \\
2 \text { Fathers }\end{array}$ & $\begin{array}{l}20 \text { SSI } \\
20 \text { Q } \\
\text { (demographic) }\end{array}$ & $\begin{array}{l}\text { Self-selecting } \\
\text { then purposive }\end{array}$ & $\begin{array}{l}\text { To explore parent perceptions of } \\
\text { services for their children with } \\
\text { ADHD }\end{array}$ & Grounded Theory & $\begin{array}{l}\text { Constant comparative } \\
\text { method }\end{array}$ \\
\hline $\begin{array}{l}\text { Watson (2011) } \\
\text { UK }\end{array}$ & 1 & Mother & 1 narrative & Purposive & $\begin{array}{l}\text { Examine events surrounding the } \\
\text { diagnosis of ADHD in her son }\end{array}$ & $\begin{array}{l}\text { Narrative analysis, } \\
\text { theories of stigma, mother } \\
\text { blame; use of satire }\end{array}$ & Narrative inquiry \\
\hline \multicolumn{8}{|c|}{ Pupils diagnosed with ADHD, their teachers, parents and peers } \\
\hline $\begin{array}{l}\text { Edwards } \\
\text { (2008) } \\
\text { New Zealand }\end{array}$ & 14 & $\begin{array}{l}6 \text { Children; } 7 \\
\text { Parents; } 1 \text { Teacher }\end{array}$ & $\begin{array}{l}28 \text { SSI, picture } \\
\text { cards used with } \\
\text { children. }\end{array}$ & Reputational & $\begin{array}{l}\text { To identify effective strategies that } \\
\text { help children diagnosed with } \\
\text { ADHD in this study learn }\end{array}$ & $\mathrm{n} / \mathrm{r}$ & $\begin{array}{l}\text { Narrative and thematic } \\
\text { analysis }\end{array}$ \\
\hline $\begin{array}{l}\text { Guevara et al } \\
\text { (2005) } \\
\text { USA }\end{array}$ & $\begin{array}{l}\mathrm{n} / \mathrm{r}(42- \\
130)\end{array}$ & $\begin{array}{l}\text { Regular and special } \\
\text { education teachers; } \\
\text { paediatricians and } \\
\text { paediatric nurses; } \\
\text { psychologists and } \\
\text { social workers; } \\
\text { parents of children } \\
\text { with ADHD }\end{array}$ & $13 \mathrm{FG}$ & $\begin{array}{l}\text { Purposive and } \\
\text { then self-selecting }\end{array}$ & $\begin{array}{l}\text { To identify system-level problems } \\
\text { in the communication and } \\
\text { coordination of care provided to } \\
\text { minority children with ADHD }\end{array}$ & $\begin{array}{l}\text { Root cause analysis } \\
\text { (RCA) }\end{array}$ & $\begin{array}{l}\text { Constant comparative } \\
\text { method }\end{array}$ \\
\hline $\begin{array}{l}\text { Hands (2009) } \\
\text { USA }\end{array}$ & 3 & 2 Teachers; 1 Pupil & $\begin{array}{l}5.5 \text { hours O } \\
\text { (classroom); } 4 \text { SSI }\end{array}$ & Reputational & $\begin{array}{l}\text { To investigate experiences of a } \\
\text { gifted pupil with ADHD and a } \\
\text { Nonverbal learning disability }\end{array}$ & $\mathrm{n} / \mathrm{r}$ & $\begin{array}{l}\text { Constant comparative } \\
\text { method }\end{array}$ \\
\hline $\begin{array}{l}\text { Hughes (2007) } \\
\text { UK }\end{array}$ & 51 & $\begin{array}{l}14 \text { pupils; } 14 \\
\text { parents; } 14 \text { teachers; } \\
9 \text { clinicians }\end{array}$ & $51 \mathrm{SSI}$ & $\begin{array}{l}\text { Opportunistic } \\
\text { then reputational }\end{array}$ & $\begin{array}{l}\text { To identify the type of support } \\
\text { required for pupils with ADHD }\end{array}$ & Constructionist & $\begin{array}{l}\text { Case studies of child, } \\
\text { teacher and parent }\end{array}$ \\
\hline $\begin{array}{l}\text { Koro- } \\
\text { Ljungberg et } \\
\text { al. (2011) } \\
\text { USA }\end{array}$ & 15 & $\begin{array}{l}7 \text { mothers; } 8 \\
\text { teachers }\end{array}$ & $2 \mathrm{FG}$ & Purposive & $\begin{array}{l}\text { To increase understanding of } \\
\text { existing practices between parents } \\
\text { of students with ADHD and their } \\
\text { teachers }\end{array}$ & $\begin{array}{l}\text { Constructionist and } \\
\text { theories and models of } \\
\text { Parent-teacher } \\
\text { communication practice }\end{array}$ & $\begin{array}{l}\text { Domain analysis and } \\
\text { discourse analysis }\end{array}$ \\
\hline $\begin{array}{l}\text { Rafalovich } \\
(2004) \\
\text { Canada and } \\
\text { USA }\end{array}$ & 81 & $\begin{array}{l}25 \text { teachers; } 30 \\
\text { parents; } 26 \\
\text { clinicians }\end{array}$ & $\begin{array}{l}81 \text { SSI (telephone } \\
\text { or face to face) }\end{array}$ & Snowball & $\begin{array}{l}\text { To detail how educators } \\
\text { conceptualize the nature of ADHD } \\
\text { children }\end{array}$ & $\begin{array}{l}\text { Symbolic interactionism, } \\
\text { Grounded Theory, the } \\
\text { social construction of } \\
\text { deviance, medicalization }\end{array}$ & Grounded Theory \\
\hline $\begin{array}{l}\text { Shea and } \\
\text { Wiener (2003) } \\
\text { Canada }\end{array}$ & 12 & $\begin{array}{l}4 \text { Pupils; } 4 \text { Parents; } \\
4 \text { Teachers }\end{array}$ & $12 \mathrm{SSI}$ & $\begin{array}{l}\text { Purposive; drawn } \\
\text { from a larger } \\
\text { study }\end{array}$ & $\begin{array}{l}\text { To gain insight into the experience } \\
\text { of chronic peer victimisation for } \\
\text { boys with ADHD }\end{array}$ & Grounded Theory & $\begin{array}{l}\text { Constant comparative } \\
\text { method }\end{array}$ \\
\hline
\end{tabular}

a- Data collection: $\mathrm{SSI}=$ semi-structured interview, $\mathrm{PO}=$ participant observation, $\mathrm{Q}=$ questionnaire, $\mathrm{FG}=$ focus group

$\mathrm{b}-\mathrm{n} / \mathrm{r}=$ not reported 
c- comprised of three groups (diagnosed with ADHD, medicated; diagnosed with ADHD, not medicated; no ADHD diagnosis or symptoms)

d- The 10 participants had a range of disabilities only one of which was ADHD. Data was extracted where it was shown to be relevant to the one child with ADHD in the study.

e- Mothers of children diagnosed with ADHD (44), ADHD and learning difficulties (LD) (124), LD (148)

f- Houghton et al. (2006) was a single study that analyzed teacher and pupils interviews separately, so is included in both pupil and teacher subreviews. 
Study author (year)

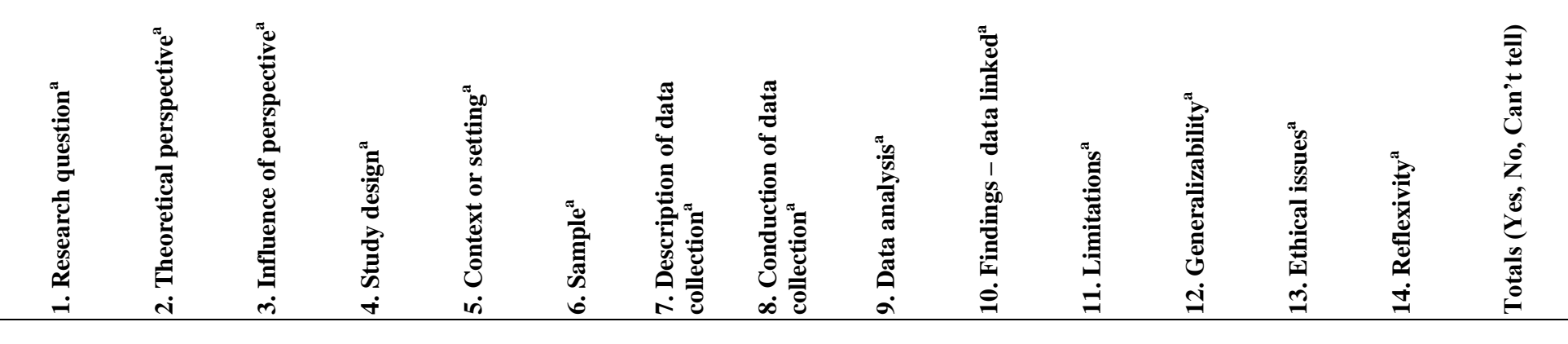

Pupil views; $n=11^{b}$

Brice (1998)

Cooper and Shea (1998)

Exley (2008)

Friio (1999)

Houghton et at. (2006)

Kendall (2003)

McDannel (2005)

Prosser (2006)

Singh (2011)

Taylor and Houghton (2008)

Wolfberg et al. (1999)

\section{$\mathrm{Y} \quad \mathrm{Y}$}

Totals for Pupil views

$11,0,0 \quad 11,0,0 \quad 10,1,0 \quad 11,0,0 \quad 8,3,0$

$\mathrm{Y} \quad \mathrm{N}$

$\mathrm{CT}^{\mathrm{e}} \mathrm{Y}$

Teacher views; $n=11^{b}$

Arcia et al.(2000)

Bailey and Thompson (2009) Y

Einarsdottir (2008)

Hillman (2011)

Houghton et al (2006)

Hong (2008)

Jones (2008)

Lee (200)

Ljusberg (2011a)

$\begin{array}{llllllllll}\mathrm{Y}^{\mathrm{c}} & \mathrm{Y} & \mathrm{Y} & \mathrm{Y} & \mathrm{N}^{\mathrm{d}} & \mathrm{Y} & \mathrm{N} & \mathrm{CT}^{\mathrm{e}} & \mathrm{Y} & \mathrm{Y} \\ \mathrm{Y} & \mathrm{Y} & \mathrm{Y} & \mathrm{Y} & \mathrm{N} & \mathrm{Y} & \mathrm{Y} & \mathrm{Y} & \mathrm{Y} & \mathrm{Y} \\ \mathrm{Y} & \mathrm{Y} & \mathrm{Y} & \mathrm{Y} & \mathrm{Y} & \mathrm{N} & \mathrm{Y} & \mathrm{Y} & \mathrm{N} & \mathrm{Y} \\ \mathrm{Y} & \mathrm{Y} & \mathrm{N} & \mathrm{Y} & \mathrm{Y} & \mathrm{Y} & \mathrm{Y} & \mathrm{Y} & \mathrm{Y} & \mathrm{Y} \\ \mathrm{Y} & \mathrm{Y} & \mathrm{Y} & \mathrm{Y} & \mathrm{Y} & \mathrm{Y} & \mathrm{Y} & \mathrm{Y} & \mathrm{Y} & \mathrm{Y} \\ \mathrm{Y} & \mathrm{Y} & \mathrm{Y} & \mathrm{Y} & \mathrm{Y} & \mathrm{Y} & \mathrm{Y} & \mathrm{Y} & \mathrm{Y} & \mathrm{Y} \\ \mathrm{Y} & \mathrm{Y} & \mathrm{Y} & \mathrm{Y} & \mathrm{Y} & \mathrm{Y} & \mathrm{Y} & \mathrm{Y} & \mathrm{Y} & \mathrm{Y} \\ \mathrm{Y} & \mathrm{Y} & \mathrm{Y} & \mathrm{Y} & \mathrm{Y} & \mathrm{Y} & \mathrm{Y} & \mathrm{Y} & \mathrm{Y} & \mathrm{Y} \\ \mathrm{Y} & \mathrm{Y} & \mathrm{Y} & \mathrm{Y} & \mathrm{N} & \mathrm{Y} & \mathrm{Y} & \mathrm{Y} & \mathrm{Y} & \mathrm{Y} \\ \mathrm{Y} & \mathrm{Y} & \mathrm{Y} & \mathrm{Y} & \mathrm{Y} & \mathrm{Y} & \mathrm{Y} & \mathrm{Y} & \mathrm{Y} & \mathrm{Y} \\ \mathrm{Y} & \mathrm{Y} & \mathrm{Y} & \mathrm{Y} & \mathrm{Y} & \mathrm{Y} & \mathrm{Y} & \mathrm{Y} & \mathrm{Y} & \mathrm{Y}\end{array}$

$\mathrm{Y}$
$\mathrm{Y}$
$\mathrm{N}$
$\mathrm{Y}$
$\mathrm{N}$
$\mathrm{N}$
$\mathrm{Y}$
$\mathrm{N}$
$\mathrm{N}$
$\mathrm{N}$
$\mathrm{Y}$

$\begin{array}{llll}\text { Y } & \text { Y } & \text { Y } & 11,2,1 \\ \text { Y } & \text { CT } & \text { N } & 11,2,1 \\ \text { CT } & \text { Y } & \text { N } & 9,4,1 \\ \text { Y } & \text { Y } & \text { Y } & 13,1,0 \\ \text { CT } & \text { Y } & \text { Y } & 12,1,1 \\ \text { CT } & \text { Y } & \text { Y } & 12,1,1 \\ \text { CT } & \text { Y } & \text { Y } & 13,0,1 \\ \text { Y } & \text { Y } & \text { Y } & 13,1,0 \\ \text { Y } & \text { CT } & \text { N } & 10,3,1 \\ \text { CT } & \text { Y } & \text { Y } & 12,1,1 \\ \text { CT } & \text { Y } & \text { N } & 12,1,1 \\ 5,0,6 & 9,0,2 & 7,4,0 & 128,17,9\end{array}$

$10,1,0 \quad 10,1,0 \quad 10,0,1 \quad 10,1,0 \quad 11,0,0 \quad 5,6,0$

$\begin{array}{llll}0 & 10,0,1 \quad 10,1,0 \quad 11,0,0\end{array}$

$\begin{array}{llll} & & & \\ \text { Y } & \text { Y } & \text { Y } & \text { Y } \\ \text { Y } & \text { Y } & \text { Y } & \text { N } \\ \text { CT } & \text { Y } & \text { CT } & \text { Y } \\ \text { Y } & \text { CT } & \text { Y } & \text { Y } \\ \text { CT } & \text { Y } & \text { Y } & \text { N } \\ \text { Y } & \text { Y } & \text { Y } & \text { Y } \\ \text { CT } & \text { Y } & \text { Y } & \text { Y } \\ \text { Y } & \text { Y } & \text { Y } & \text { Y }\end{array}$

CT
Y
Y
Y
Y
Y
Y
Y
Y

$\begin{array}{llll}\text { Y } & \text { Y } & \text { N } & 10,2,2 \\ \text { CT } & \text { Y } & \text { Y } & 11,2,1 \\ \text { Y } & \text { CT } & \text { N } & 9,3,2 \\ \text { Y } & \text { Y } & \text { N } & 11,2,1 \\ \text { Y } & \text { CT } & \text { N } & 9,3,2 \\ \text { CT } & \text { CT } & \text { Y } & 7,3,4 \\ \text { CT } & \text { Y } & \text { Y } & 13,0,1 \\ \text { Y } & \text { CT } & \text { Y } & 11,1,2 \\ \text { Y } & \text { Y } & \text { N } & 12,2,0\end{array}$




\begin{tabular}{|c|c|c|c|c|c|c|c|c|c|c|c|c|c|c|c|}
\hline Study author (year) & 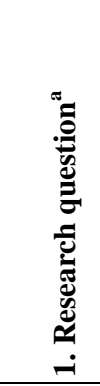 & 芯 & 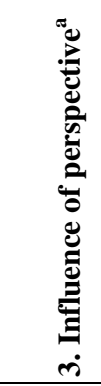 & 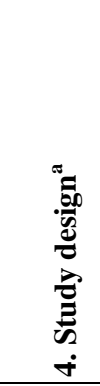 & 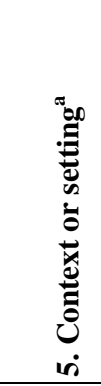 & 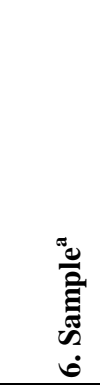 & 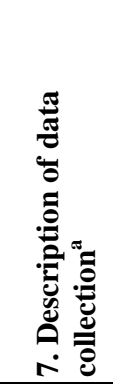 & 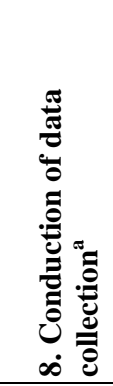 & 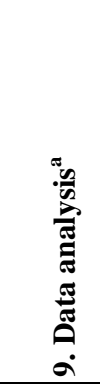 & 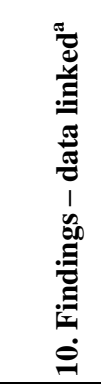 & 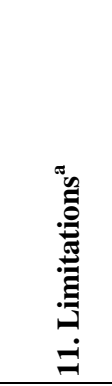 & 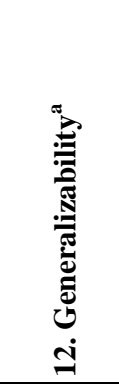 & 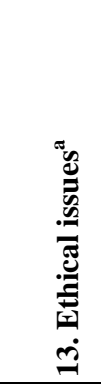 & 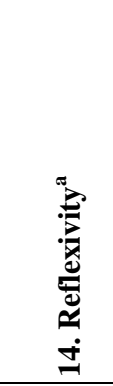 & 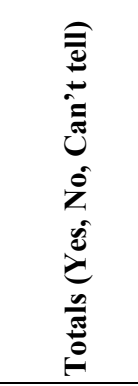 \\
\hline McMahon (2012) & $\mathrm{Y}$ & $\mathrm{Y}$ & $\mathrm{Y}$ & $\mathrm{Y}$ & $\mathrm{Y}$ & $\mathrm{Y}$ & $\mathrm{Y}$ & $\mathrm{Y}$ & $\mathrm{Y}$ & $\mathrm{Y}$ & $\mathrm{N}$ & $\mathrm{Y}$ & $\mathrm{Y}$ & $\mathrm{Y}$ & $13,1,0$ \\
\hline Nowacek and Mamlin (2007) & $\mathrm{Y}$ & $\mathrm{Y}$ & $\mathrm{Y}$ & $\mathrm{Y}$ & $\mathrm{Y}$ & $\mathrm{Y}$ & $\mathrm{Y}$ & $\mathrm{Y}$ & $\mathrm{Y}$ & CT & $\mathrm{Y}$ & $\mathrm{N}$ & Y & $\mathrm{N}$ & $11,3,1$ \\
\hline $\begin{array}{l}\text { Totals for Teacher views } \\
\text { (Yes, No, Can't Tell) }\end{array}$ & $11,0,0$ & $9,2,0$ & $9,0,2$ & $11,0,0$ & $10,1,0$ & $7,0,4$ & $11,0,0$ & $10,0,1$ & $9,2,0$ & $9,0,2$ & $4,7,0$ & $6,1,4$ & $8,0,3$ & $6,5,0$ & $118,20,17$ \\
\hline \multicolumn{16}{|l|}{ Parent views; $n=6$} \\
\hline Carpenter and Austin (2008) & $\mathrm{Y}$ & $\mathrm{Y}$ & $\mathrm{Y}$ & $\mathrm{Y}$ & $\mathrm{N}$ & $\mathrm{Y}$ & $\mathrm{Y}$ & $\mathrm{Y}$ & $\mathrm{Y}$ & $\mathrm{Y}$ & $\mathrm{N}$ & $\mathrm{Y}$ & $\mathrm{Y}$ & $\mathrm{Y}$ & $12,2,0$ \\
\hline Hibbitts (2010) & $\mathrm{Y}$ & $\mathrm{Y}$ & $\mathrm{Y}$ & $\mathrm{Y}$ & $\mathrm{Y}$ & $\mathrm{Y}$ & $\mathrm{Y}$ & $\mathrm{Y}$ & $\mathrm{Y}$ & $\mathrm{Y}$ & $\mathrm{Y}$ & $\mathrm{Y}$ & $\mathrm{Y}$ & $\mathrm{Y}$ & $14,0,0$ \\
\hline Malacrida $(2001 ; 2004)$ & $\mathrm{Y}$ & $\mathrm{Y}$ & $\mathrm{Y}$ & $\mathrm{Y}$ & $\mathrm{Y}$ & $\mathrm{Y}$ & $\mathrm{Y}$ & $\mathrm{Y}$ & $\mathrm{Y}$ & $\mathrm{Y}$ & $\mathrm{Y}$ & $\mathrm{Y}$ & $\mathrm{Y}$ & $\mathrm{N}$ & $13,1,0$ \\
\hline Margalit et al.(2010) & $\mathrm{Y}$ & $\mathrm{N}$ & $\mathrm{CT}$ & $\mathrm{Y}$ & $\mathrm{Y}$ & $\mathrm{Y}$ & $\mathrm{Y}$ & $\mathrm{Y}$ & $\mathrm{Y}$ & $\mathrm{Y}$ & $\mathrm{Y}$ & $\mathrm{Y}$ & $\mathrm{Y}$ & $\mathrm{N}$ & $11,2,1$ \\
\hline Reid et al.(1996) & $\mathrm{Y}$ & $\mathrm{N}$ & $\mathrm{CT}$ & $\mathrm{Y}$ & $\mathrm{Y}$ & $\mathrm{Y}$ & $\mathrm{Y}$ & $\mathrm{Y}$ & $\mathrm{Y}$ & Y & $\mathrm{Y}$ & $\mathrm{N}$ & $\mathrm{Y}$ & $\mathrm{N}$ & $10,3,1$ \\
\hline Watson (2011) & $\mathrm{Y}$ & $\mathrm{Y}$ & $\mathrm{Y}$ & $\mathrm{CT}$ & $\mathrm{Y}$ & $\mathrm{N}$ & $\mathrm{Y}$ & $\mathrm{Y}$ & $\mathrm{Y}$ & $\mathrm{Y}$ & $\mathrm{Y}$ & $\mathrm{CT}$ & $\mathrm{Y}$ & $\mathrm{Y}$ & $11,1,2$ \\
\hline $\begin{array}{l}\text { Totals for Parent views } \\
\text { (Yes, No, Can't Tell) }\end{array}$ & $6,0,0$ & $4,2,0$ & $4,0,2$ & $5,0,1$ & $5,1,0$ & $5,1,0$ & $6,0,0$ & $6,0,0$ & $6,0,0$ & $6,0,0$ & $5,1,0$ & $4,1,1$ & $6,0,0$ & $3,3,0$ & $71,9,4$ \\
\hline \multicolumn{16}{|l|}{ Mixed views; $n=7$} \\
\hline Edwards (2008) & $\mathrm{Y}$ & $\mathrm{N}$ & $\mathrm{CT}$ & $\mathrm{Y}$ & $\mathrm{N}$ & $\mathrm{Y}$ & $\mathrm{Y}$ & $\mathrm{Y}$ & $\mathrm{N}$ & $\mathrm{Y}$ & $\mathrm{Y}$ & $\mathrm{Y}$ & $\mathrm{Y}$ & $\mathrm{Y}$ & $10,3,1$ \\
\hline Guevara et al.(2005) & $\mathrm{Y}$ & $\mathrm{Y}$ & $\mathrm{Y}$ & $\mathrm{Y}$ & $\mathrm{Y}$ & $\mathrm{Y}$ & $\mathrm{N}$ & $\mathrm{CT}$ & $\mathrm{Y}$ & $\mathrm{Y}$ & $\mathrm{Y}$ & $\mathrm{Y}$ & $\mathrm{Y}$ & $\mathrm{N}$ & $11,2,1$ \\
\hline Hands (2009) & $\mathrm{Y}$ & $\mathrm{Y}$ & $\mathrm{Y}$ & $\mathrm{Y}$ & $\mathrm{Y}$ & $\mathrm{N}$ & $\mathrm{Y}$ & $\mathrm{Y}$ & $\mathrm{Y}$ & $\mathrm{Y}$ & $\mathrm{N}$ & $\mathrm{N}$ & $\mathrm{Y}$ & $\mathrm{Y}$ & $11,3,0$ \\
\hline Hughes (2007) & $\mathrm{N}$ & $\mathrm{Y}$ & $\mathrm{Y}$ & $\mathrm{Y}$ & $\mathrm{N}$ & $\mathrm{Y}$ & $\mathrm{Y}$ & $\mathrm{Y}$ & $\mathrm{Y}$ & $\mathrm{Y}$ & $\mathrm{N}$ & $\mathrm{CT}$ & $\mathrm{Y}$ & $\mathrm{N}$ & $9,4,1$ \\
\hline Koro-Ljungberg et al. (2012) & $\mathrm{Y}$ & $\mathrm{Y}$ & $\mathrm{Y}$ & $\mathrm{Y}$ & $\mathrm{Y}$ & $\mathrm{Y}$ & $\mathrm{Y}$ & $\mathrm{Y}$ & $\mathrm{Y}$ & $\mathrm{Y}$ & $\mathrm{Y}$ & $\mathrm{Y}$ & $\mathrm{Y}$ & $\mathrm{N}$ & $13,1,0$ \\
\hline Rafalovich (2004) & $\mathrm{Y}$ & $\mathrm{Y}$ & $\mathrm{Y}$ & $\mathrm{Y}$ & $\mathrm{Y}$ & $\mathrm{Y}$ & $\mathrm{Y}$ & $\mathrm{Y}$ & $\mathrm{Y}$ & $\mathrm{Y}$ & $\mathrm{N}$ & $\mathrm{Y}$ & $\mathrm{Y}$ & $\mathrm{N}$ & $12,2,0$ \\
\hline Shea and Wiener (2003) & $\mathrm{Y}$ & $\mathrm{Y}$ & $\mathrm{Y}$ & $\mathrm{Y}$ & $\mathrm{N}$ & $\mathrm{Y}$ & $\mathrm{Y}$ & $\mathrm{Y}$ & $\mathrm{Y}$ & $\mathrm{Y}$ & $\mathrm{N}$ & $\mathrm{CT}$ & $\mathrm{Y}$ & $\mathrm{N}$ & $10,3,1$ \\
\hline $\begin{array}{l}\text { Totals from Mixed views } \\
\text { (Yes, No, Can't Tell) }\end{array}$ & $6,1,0$ & $6,1,0$ & $6,0,1$ & $7,0,0$ & $4,3,0$ & $6,1,0$ & $6,1,0$ & $7,0,0$ & $6,1,0$ & $7,0,0$ & $3,4,0$ & $4,1,2$ & $7,0,0$ & $2,5,0$ & $77,18,4$ \\
\hline $\begin{array}{l}\text { Totals for all papers in } \\
\text { Review } \\
\text { (n=34b) } \\
\text { (Yes, No, Can't Tell) }\end{array}$ & $33,1,0$ & $29,5,0$ & $28,1,5$ & $32,0,2$ & $26,8,0$ & $26,3,5$ & $31,3,0$ & $29,2,3$ & $29,5,0$ & $32,0,2$ & $17,17,0$ & $18,3,13$ & $28,0,6$ & $17,17,0$ & $374,64,39$ \\
\hline
\end{tabular}


a For full quality appraisal questions, see Table 1

b One study; Houghton et al (2006) contributed to both pupil and teacher views

c Y=yes,

d $\mathrm{N}=$ no,

e CT=can't tell 